This document is the accepted manuscript version of the following article: Nied, D., Enemark-Rasmussen, K., L'Hopital, E., Skibsted, J., \& Lothenbach, B. (2016). Properties of magnesium silicate hydrates (M-SH). Cement and Concrete Research, 79, 323-332. http://doi.org/10.1016/j.cemconres.2015.10.003

This accepted manuscript is made available under the CC-BY-NC-ND 4.0 license

http://creativecommons.org/ licences/by-nc-nd/4.0/

\title{
1 Properties of magnesium silicate hydrates (M-S-H)
}

2 Dominik Nied ${ }^{1,2^{*}}$, Kasper Enemark-Rasmussen ${ }^{3}$, Emilie L'Hopital $^{2}$, Jørgen Skibsted ${ }^{3}$,

3 Barbara Lothenbach ${ }^{2}$

${ }^{1}$ HeidelbergCement Technology Center GmbH, 69181 Leimen, Germany email: dominik.nied@htc-gmbh.com; Tel: +49 17661258675

${ }^{2}$ Empa, Laboratory for Concrete \& Construction Chemistry, 8600 Duebendorf, Switzerland

${ }^{3}$ Department of Chemistry and Interdisciplinary Nanoscience Center (iNANO), Aarhus University, DK-8000 Aarhus C, Denmark

Investigations of synthetic magnesium silicate hydrate (M-S-H) samples have shown that M-S-H aged for 1 year can exhibit variable compositions with molar $\mathrm{Mg} / \mathrm{Si}$ ratios in the range $0.7 \leq \mathrm{Mg} / \mathrm{Si} \leq 1.5$. At lower $\mathrm{Mg} / \mathrm{Si}$ ratio, additional silica is present whereas brucite is observed for $\mathrm{Mg} / \mathrm{Si} \geq 1.3$. FT-IR and ${ }^{29} \mathrm{Si} \mathrm{NMR}$ data reveal a high degree of silicate polymerisation, indicating the formation of silicate sheets. TGA shows the presence of bound water and of hydroxyl groups bound to $\mathrm{Mg}$ and as silanol groups in the M-S-H, in

17 accord with ${ }^{29} \mathrm{Si}\left\{{ }^{1} \mathrm{H}\right\} \mathrm{CP} / \mathrm{MAS}$ and high-speed ${ }^{1} \mathrm{H}$ NMR measurements. Raman and XRD 18 data suggest that the M-S-H structure is related to a disordered talc precursor at low $19 \mathrm{Mg} / \mathrm{Si}$ and to a serpentine precursor at high $\mathrm{Mg} / \mathrm{Si}$ ratio. Solubility products for $\mathrm{M}-\mathrm{S}-\mathrm{H}$ phases were calculated on basis of the compositions of the aqueous solutions and a 21 solid solution model was suggested.

Keywords: MgO - D; Magnesium silicate hydrate (M-S-H); Solubility; clay-cement interface; Spectroscopy - C. 


\section{Introduction}

27 There is a growing interest for using magnesium silicate hydrate $(\mathrm{M}-\mathrm{S}-\mathrm{H})$ as potential low-pH cements for e.g. nuclear-waste encapsulation [1]. M-S-H may also form on the surface of cement in contact with ground water containing magnesium sulphate $[2,3]$ and in the interaction zone between cement and clays [4, 5], i.e., under conditions important for $\mathrm{CO}_{2}$ storage in deep reservoirs and for disposal of radioactive wastes in underground repositories. Recent investigations have shown that the decrease of $\mathrm{pH}$ near the cement - clay interface and the diffusion of magnesium ions from the clay towards the cement can lead to a magnesium enriched zone at the interface [6, 7]. In these magnesium enriched zones magnesium silicate hydrates, which exhibit a gel-like structure with little or no aluminium, are observed. Although analyses of solid M-S-H phases have been reported in the literature, the properties, conditions of formation and solubility of such M-S-H phases are not well investigated. M-S-H synthesized at room temperature has been characterised showing evidence for low crystalline structure consisting of silicate sheets [8-10]. Hydrothermal synthesis routes for M-S-H lead to the

41 formation of crystalline talc at low $\mathrm{Mg} / \mathrm{Si}$ [11-14] and of crystalline serpentine at high $\mathrm{Mg} / \mathrm{Si}[14,15]$ for temperatures above $200^{\circ} \mathrm{C}$. But it is neither known how much $\mathrm{Mg}$ can be incorporated in such M-S-H phases nor its thermodynamic solubility constants.

44 In the present paper the composition and structure of $\mathrm{M}-\mathrm{S}-\mathrm{H}$ prepared from $\mathrm{MgO}$ and $45 \mathrm{SiO}_{2}$ at room temperature is investigated. The composition of the aqueous solutions is 46 determined and used to calculate tentative solubility products. The solid phases are 
47 analysed by combining conventional methods (XRD, TGA, IR, Raman, ${ }^{1} \mathrm{H}$, and ${ }^{29}$ Si MAS

48 NMR) with innovative ${ }^{25} \mathrm{Mg}$ NMR spectroscopy. ${ }^{25} \mathrm{Mg}$ NMR is employed for the first time 49 in studies of cement phases to characterize the local structural environments of the $\mathrm{Mg}^{2+}$ 50 ions.

\section{Materials and methods}

\subsection{M-S-H synthesis}

54 The M-S-H samples were synthesised by mixing appropriate quantities of MgO (Merck, 55 pro analysis, $>97$ wt. $\% \mathrm{MgO},<1.5 \% \mathrm{CO}_{2}$ and $\left.<0.1 \% \mathrm{CaO}\right)$ and silica fume $\left(\mathrm{SiO}_{2}\right.$, Aerosil 200, >99.8\% $\left.\mathrm{SiO}_{2}\right)$. Samples targeting six different $\mathrm{Mg} / \mathrm{Si}$ molar ratios $(0.4 ; 0.6$; $0.8 ; 1.0 ; 1.3$ and 1.7$)$ were prepared and equilibrated at $20^{\circ} \mathrm{C}$ for one year. All samples were prepared in polyethylene (PE) containers with a water/solid ratio of 45 to ensure

59 the availability of sufficient water. The synthesis and sample handling was performed in

60 a $\mathrm{N}_{2}$ filled glove box to minimize $\mathrm{CO}_{2}$ contamination. The samples were placed on a 61 horizontal shaker (100 rpm) during the reaction time of 1 year. After 1 year, the samples were filtered $(0.45 \mu \mathrm{m}$ Nylon filter), rinsed first with approximately $50 \mathrm{~mL}$ of $1: 1$ water ethanol solution and then with $50 \mathrm{~mL} 94 \%$ ethanol solution in a $\mathrm{N}_{2}$ filled glove. The solids were freeze dried for seven days, ground in an agate mortar and then stored in $\mathrm{N}_{2}$ filled desiccators over a saturated aqueous $\mathrm{CaCl}_{2}$ solution at approximately $30 \%$ relative humidity until analysis. 
A Mettler Toledo TGA/SDTA 8513 instrument was used for thermogravimetric analysis (TGA). Samples of 30 to $40 \mathrm{mg}$ were heated in a nitrogen atmosphere at $20^{\circ} \mathrm{C} / \mathrm{min}$ from 30 to $980^{\circ} \mathrm{C}$. The amount of brucite was quantified from the weight loss between 330 and $480^{\circ} \mathrm{C}$ using the tangential method [16].

X-Ray Diffraction (XRD) data were collected using a PANalytical X'Pert Pro MPD diffractometer in a $\theta-2 \theta$ configuration, applying $\operatorname{CuK}_{\alpha}$ radiation $(\lambda=1.5406 \AA)$ with a fixed divergence slit size of $0.5^{\circ}$ and a rotating sample stage. The samples were scanned between $5^{\circ}$ and $75^{\circ} 2 \theta$ using a step size of $0.017^{\circ} 2 \theta$ with the $X^{\prime}$ Celerator detector.

The infrared (IR) spectra were recorded on a Bruker Tensor 27 FT-IR spectrometer using the ATR technique (attenuated total reflection) on bulk material and a step size of $1.9 \mathrm{~cm}^{-1}$. The data are reported in wavenumbers $\left(\mathrm{cm}^{-1}\right)$.

80 The Raman spectra were measured with a Bruker Senterra instrument of $5 \mathrm{~cm}^{-1}$ 81 spectral resolution, using a $532 \mathrm{~nm}$ laser $(20 \mathrm{~mW})$ at room temperature. The spectral acquisition time was 10 seconds and 5 spectra were accumulated for each sample in the frequency ranges of $110-1560 \mathrm{~cm}^{-1}$ and $2700-3800 \mathrm{~cm}^{-1}$.

84 The single-pulse ${ }^{29} \mathrm{Si}$ MAS NMR spectra were acquired at $79.49 \mathrm{MHz}$ on a Bruker Avance 400 NMR spectrometer using a $7 \mathrm{~mm}$ CP/MAS probe, a spinning speed of $v_{R}=$ $4500 \mathrm{~Hz}$, a $30^{\circ}$ excitation pulse of $2.5 \mu \mathrm{s}\left(\gamma \mathrm{B}_{1} / 2 \pi=33 \mathrm{kHz}\right)$, a relaxation delay of $60 \mathrm{~s}$,

87 and ${ }^{1} \mathrm{H}$ TPPM decoupling $\left(\gamma \mathrm{B}_{2} / 2 \pi=42 \mathrm{kHz}\right)$ during acquisition. The ${ }^{29} \mathrm{Si}\left\{{ }^{1} \mathrm{H}\right\} \mathrm{CP} / \mathrm{MAS}$ NMR spectra were recorded on a Varian-Unity 400 spectrometer using a CP/MAS NMR 
89 probe for $5 \mathrm{~mm}$ o.d. rotors, a spinning speed of $v_{R}=4.0 \mathrm{kHz}$, and rf field strengths of $90 \gamma \mathrm{B}_{1} / 2 \pi \approx \gamma \mathrm{B}_{2} / 2 \pi=33 \mathrm{kHz}$ for the $\mathrm{CP}$ transfer with contact time of $1.5 \mathrm{~ms}$, and $\gamma \mathrm{B}_{2} / 2 \pi=$ $9162 \mathrm{kHz}$ for the subsequent ${ }^{1} \mathrm{H}$ TPPM decoupling during acquisition. The chemical shifts 92 of the ${ }^{29} \mathrm{Si}$ MAS NMR spectra were referenced to an external sample of 93 tetramethylsilane (TMS). The ${ }^{29}$ Si MAS NMR spectra were analysed by least-squares 94 fitting of a combination of Gaussian and Lorentzian peak shapes to the experimental 95 spectra. The amount of nanosilica/silica fume was estimated from the intensity of the $Q^{4}$ 96 peak at $-110 \mathrm{ppm}$.

97 The ${ }^{25} \mathrm{Mg}$ MAS NMR spectra were obtained on a Varian Direct Drive VNMRS-600 (14.1

$98 \mathrm{~T})$ spectrometer using a home-built CP/MAS NMR probe for $5 \mathrm{~mm}$ o.d. zirconia/ $\mathrm{Si}_{3} \mathrm{~N}_{4}$ 99 rotors and a spinning speed of $v_{R}=12 \mathrm{kHz}$. The spectra were acquired with the Hahn 100 spin-echo pulse sequence, employing quadrupolar $\pi / 2-$ and $\pi$-pulses with pulse widths 101 of $2.4 \mu \mathrm{s}$ and $4.8 \mu \mathrm{s}$, respectively $\left(I=5 / 2, \gamma B_{1} / 2 \pi=35 \mathrm{kHz}\right)$, and evolution/refocusing 102 delays of $83 \mu \mathrm{s}\left(=1 / v_{\mathrm{R}}\right) .{ }^{1} \mathrm{H}$ TPPM decoupling $\left(\gamma B_{2} / 2 \pi=42 \mathrm{kHz}\right)$ was applied during the 103 spin-echo period and acquisition. A relaxation delay of $4 \mathrm{~s}$ was used and typically 10460.000 scans were accumulated. The ${ }^{25} \mathrm{Mg}$ chemical shifts are referenced to an 105 aqueous $1.0 \mathrm{M}$ solution of $\mathrm{Mg}\left(\mathrm{NO}_{3}\right)_{2}$, using solid $\mathrm{MgO}\left(\delta\left({ }^{25} \mathrm{Mg}\right)=26.05 \mathrm{ppm}\right)$ as a 106 secondary reference.

107 The ${ }^{1} \mathrm{H}$ MAS NMR experiments were obtained on a Varian Direct Drive VNMRS-600 108 (14.1 T) spectrometer using a Varian FastMAS ${ }^{\mathrm{TM}}$ triple-tuned NMR probe for $1.6 \mathrm{~mm}$ 109 o.d. zirconia rotors. The experiments employed a spinning speed of $v_{R}=40 \mathrm{kHz}$, a 110 pulse width of $\tau_{p}=1.9 \mu \mathrm{s}$ for $\gamma B_{1} / 2 \pi=130 \mathrm{kHz}$, and a 10 -s relaxation delay. The ${ }^{1} \mathrm{H}$ 
111 NMR spectra are referenced to TMS using a solid sample of adamantane $\left(\delta\left({ }^{1} H\right)=1.77\right.$ ppm) as a secondary reference.

115 The $\mathrm{pH}$ measurements were carried out immediately after filtration using small aliquots

116 of the pore solution with a Knick pH meter ( $\mathrm{pH}-$ Meter 766) equipped with a Knick SE100

117 electrode. The $\mathrm{pH}$ electrode was calibrated with CertiPUR ${ }^{\circledR}$ buffer solutions from Merck $118\left(\mathrm{pH} 4.01\right.$ with potassium hydrogen phthalate, $\mathrm{pH} 7$ with $\mathrm{KH}_{2} \mathrm{PO}_{4} / \mathrm{Na}_{2} \mathrm{HPO}_{4}$ and $\mathrm{pH}$ 11912.00 with $\mathrm{NaOH} / \mathrm{Na}_{2} \mathrm{HPO}_{4}$ ). The $\mathrm{pH}$ measured in the filtered solutions were $0.3 \mathrm{pH}$ units 120 lower than the $\mathrm{pH}$ values measured directly in the suspensions as charge balancing 121 anions such as hydroxides can be removed during filtration [17]. The reported $\mathrm{pH}$ values 122 are corrected to refer to the $\mathrm{H}^{+}$activity in the unfiltered solutions. Another part of the 123 liquid phase was diluted in ratios of $1: 10,1: 100$ and 1:1000 with MilliQ $\mathrm{H}_{2} \mathrm{O}$ immediately 124 after filtration and used for ionic chromatography (IC) analysis. The dissolved 125 concentrations of $\mathrm{Mg}$ and Si were quantified using a Dionex DP series ICS-3000 ionic 126 chromatography instrument. The IC analyses are associated with a measurement error 127 of $\leq 10 \%$.

130 Thermodynamic modelling was carried out using the Gibbs free energy minimization 131 program GEMS [18]. GEMS is a general-purpose geochemical modelling code which 
computes equilibrium phase assemblage and speciation in a complex chemical system

133 from its total bulk elemental composition. Chemical interactions involving solids, solid 134 solutions, aqueous electrolytes and gas phases are considered simultaneously. The speciation of the dissolved species as well as the kind and amount of solids precipitated are calculated at $20{ }^{\circ} \mathrm{C}$ by computing the Gibbs free energy of each species for $20^{\circ} \mathrm{C}$ 137 using the thermodynamic data as given in the PSI-Nagra [19, 20] and the SUPCRT database [21]. The thermodynamic data for aqueous species as well as for many solids were taken from the PSI-Nagra thermodynamic database $[19,20]$. Additionally, for the calculations of saturation indices for talc, chrysotile and antigorite data from the SUPCRT database [21] have been used. It is important to mention that a wide range of 142 thermodynamic data for talc and chrysotile is reported in the literature (see Table 1) as 143 the thermodynamic data have been derived from measurements at high pressure and 144 temperatures. The datasets of Holland and Powel [22] and of Melekhova et al. [23] for 145 example would indicate a 6 to 8 log units higher solubility of talc and a 5 log units more soluble chrysotile than the SUPCRT database [21].

148 Table 1: Chemical composition, fraction of silicon present in $Q^{3}$ and $Q^{2}$ sites, and 149 thermodynamic properties of different magnesium silicate hydrates at $25{ }^{\circ} \mathrm{C}$ for 150 comparison.

$\begin{array}{lcccc}\text { Chemical } & \mathrm{Q}^{3}: \mathrm{Q}^{2} & \log \mathrm{K}_{\mathrm{so}}{ }^{\mathrm{b}} & \mathrm{V}^{\circ} & \text { density } \\ \text { formula }^{\mathrm{a}} & & & {\left[\mathrm{cm}^{3} / \mathrm{mol}\right]} & {\left[\mathrm{g} / \mathrm{cm}^{3}\right]}\end{array}$




\begin{tabular}{|c|c|c|c|c|c|}
\hline Brucite $[19,20]$ & $\mathrm{MH}$ & - & -11.16 & 24.6 & 2.37 \\
\hline Jimthompsonite & $\mathrm{M}_{3.33} \mathrm{~S}_{4} \mathrm{H}_{0.67}{ }^{\mathrm{c}}$ & $2: 1$ & - & 136.1 & 2.84 \\
\hline Talc [21] & $\mathrm{M}_{3} \mathrm{~S}_{4} \mathrm{H}$ & $4: 0$ & -62.9 & 136.3 & 2.78 \\
\hline Talc [22] & $M_{3} S_{4} H$ & & -54.5 & 136.3 & \\
\hline Talc [23] & $M_{3} S_{4} H$ & & -56.2 & & \\
\hline Chrysotile [21] & $\mathrm{M}_{3} \mathrm{~S}_{2} \mathrm{H}_{2}$ & $2: 0$ & -52.9 & 108.5 & 2.55 \\
\hline Chrysotile [22] & $M_{3} S_{2} H_{2}$ & & -48.2 & 107.5 & \\
\hline Antigorite [21] & $\mathrm{M}_{2.8} \mathrm{~S}_{2} \mathrm{H}_{1.8}^{\mathrm{d}}$ & $2: 0$ & -51.0 & 102.9 & 2.59 \\
\hline Antigorite [22] & $M_{2.8} S_{2} H_{1.8}^{d}$ & & -50.8 & 103.2 & \\
\hline $\mathrm{SiO}_{2}, \mathrm{am}[19,20]$ & $S$ & - & -2.71 & 29.0 & 2.07 \\
\hline \multicolumn{6}{|c|}{${ }^{a}$ The short-hand cement notation is used: $\mathrm{H}=\mathrm{H}_{2} \mathrm{O} ; \mathrm{M}=\mathrm{MgO} ; \mathrm{S}=\mathrm{SiO}_{2}$. } \\
\hline \multicolumn{6}{|c|}{$\begin{array}{l}\text { b All solubility products refer to the solubility with respect to the species } \mathrm{Mg}^{2+}, \mathrm{SiO} \\
\mathrm{H}_{2} \mathrm{O} \text {. }\end{array}$} \\
\hline
\end{tabular}

157 The measured compositions of the solutions were used to calculate ion activity products 158 (IAP) and saturation indices (SI) with respect to amorphous $\mathrm{SiO}_{2}$, brucite and talc and to 159 derive tentative solubility products $\left(\mathrm{K}_{\mathrm{SO}}\right)$ for $\mathrm{M}-\mathrm{S}-\mathrm{H}$. Saturation indices offer the possibility 160 to assess independently which solid phases could potentially form from a 161 thermodynamic point of view. The saturation index (SI) with respect to a solid is given by $162 \log \left(\mathrm{IAP} / \mathrm{K}_{\mathrm{SO}}\right)$, where the IAP is calculated from activities derived from the concentrations 163 determined in the solution and $\mathrm{K}_{\mathrm{S} 0}$ denotes the solubility product of the respective solid. 164 A positive saturation index implies oversaturation whereas a negative value reflects 
under-saturation with regard to the respective solid. All calculated saturation indices refer to the solubility products of the solids as given in Table 1.

\section{Results and Discussion}

\subsection{Solid phase Analyses}

\subsubsection{XRD and TGA}

The powder X-ray diffraction (XRD) patterns in Figure 1 show that the M-S-H syntheses lead to low crystalline phases with the same broad humps at $19.7,26.7,35.0$ and $59.9^{\circ}$ $2 \theta$ as reported earlier for M-S-H $[1,8]$. The broad humps at $\sim 20^{\circ}$ and $27^{\circ} 2 \theta$ overlap with the signal from unreacted silica gel at $\sim 21.5^{\circ} 2 \theta$ for $\mathrm{Mg} / \mathrm{Si}$ molar ratios $\leq 0.8$ (silica gel is detected by ${ }^{29}$ Si NMR, FT-IR and Raman spectroscopy, see below). The formation of brucite is observed for the high $\mathrm{Mg} / \mathrm{Si}$ samples $(\mathrm{Mg} / \mathrm{Si}=1.3$ and 1.7). The broad peaks in Figure 1 are very similar to the main reflections from talc at 9.5, 19.5, 28.6, 36.1 and $60.5^{\circ} 2 \theta$ (PDF 01-083-1768) [24]. Jimthompsonite with main reflections at 10.0, 19.5, 23.2, 28.8, 32.6 and 35.1 (PDF 98-011-0925 [25]) fits less well with the diffractograms in Figure 1. Alternatively, the broad peaks may reflect the formation of serpentine such as antigorite $\left(19.6,24.6\right.$, and $35.1^{\circ} 2 \theta$ [26], PDF 98-006-7465]) and lizardite (12.1, 19.3, 24.5 and $35.9^{\circ} 2 \theta$ [RUFF R060006]) as proposed by Walling et al. [27] or other phyllosilicates such as stevensite $\left(\left(\mathrm{Ca}_{0.5}, \mathrm{Na}\right)_{0.33}(\mathrm{Mg}, \mathrm{Fe})_{3} \mathrm{SiO}_{4} \mathrm{O}_{10}(\mathrm{OH})_{2} \cdot \mathrm{nH}_{2} \mathrm{O}\right)$ or hectorite $\left(\mathrm{Na}_{0.3}(\mathrm{Mg}, \mathrm{Li})_{3} \mathrm{Si}_{4} \mathrm{O}_{10}(\mathrm{OH})_{2}\right)$. Experimental findings and structural modelling from Roosz et al. [10] are suggesting that the investigated M-S-H samples are nano- 
crystalline and turbostratic Mg-Si phyllosilicates that cannot be straightforwardly be 187 related to any known mineral.

188 The main peaks of talc related to the interlayer distance $(9.4 \AA)$ are observed at $9.5^{\circ}$ 189 (001) and $28.6^{\circ} 2 \theta(003)$, according to PDF 01-083-1768 [24]. These peaks are very 190 broad in the case of M-S-H and shifted to slightly lower angles than those reported for 191 talc, which could be caused by a larger basal spacing for M-S-H than for talc or be an 192 effect of M-S-H nanocrystallinity as suggested by [10]. In accordance with our 193 observations, a large basal spacing has been observed at ambient temperatures for M$194 \mathrm{~S}-\mathrm{H}(\mathrm{Mg} / \mathrm{Si}=0.75)$, while synthesis at $180{ }^{\circ} \mathrm{C}$ and above resulted in $\mathrm{M}-\mathrm{S}-\mathrm{H}$ with a 195 smaller interlayer distances and the formation of talc [11, 12, 14]. In addition, the shift to 196 higher $2 \theta$ for this first peak indicates a smaller basal spacing for high Mg/Si than for low 197 Mg/Si M-S-H. 


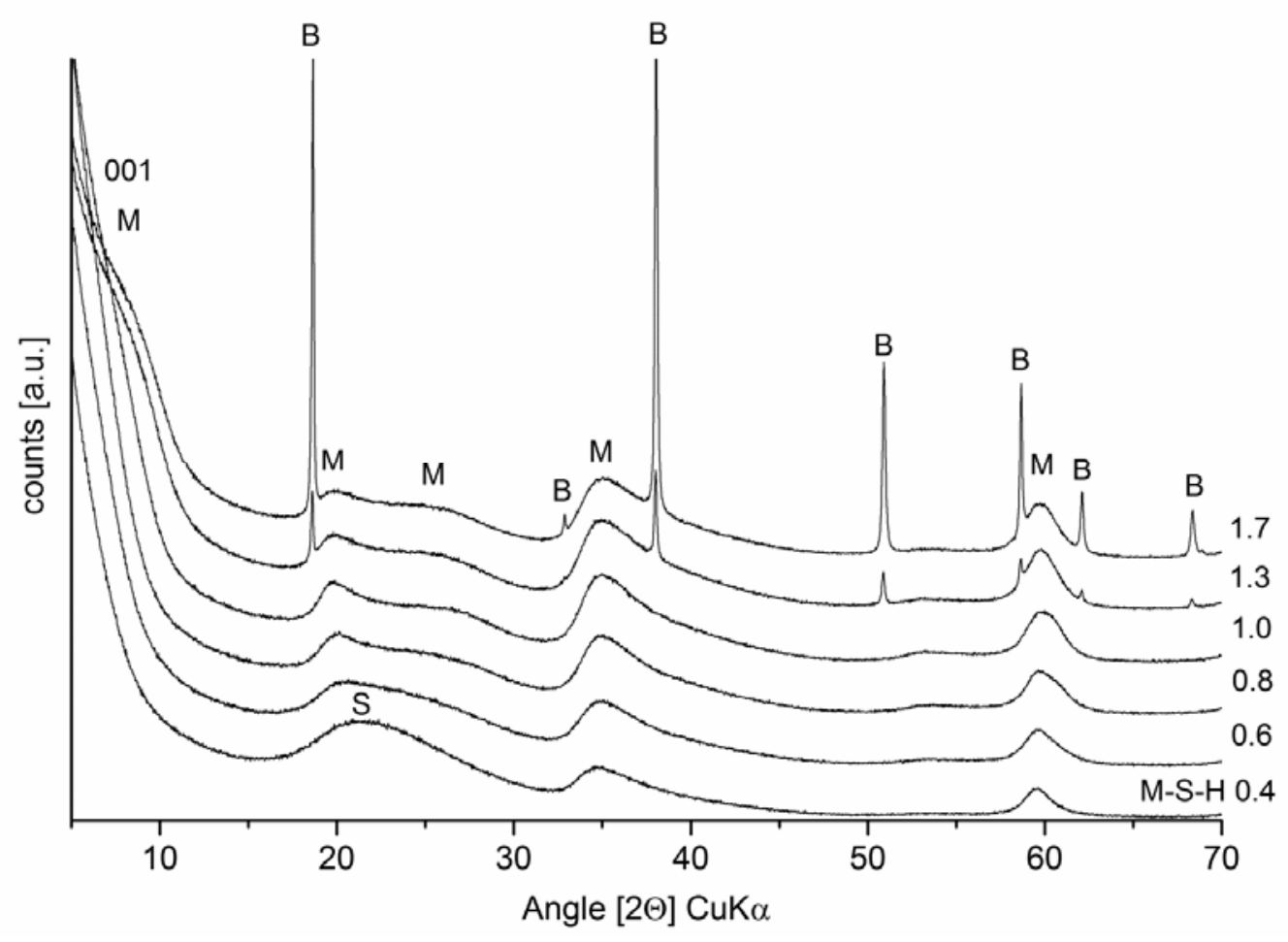

199

200 Figure 1: XRD diffractograms for the synthetic M-S-H samples with varying Mg/Si ratios.

201 B: brucite; M: M-S-H; S: unreacted $\mathrm{SiO}_{2}$.

203 The TGA data (Figure 2) show multi-step weight loss curves for the synthetic M-S-H, 204 which is in good agreement with earlier reported TGA results for M-S-H [28]. The first 205 weight loss at $30^{\circ} \mathrm{C}$ to $280^{\circ} \mathrm{C}$ is most likely related to loosely bound interlayer water, 206 while the remaining weight losses between $280^{\circ} \mathrm{C}$ to $750^{\circ} \mathrm{C}$ result from hydroxyl groups 207 bound to $\mathrm{Mg}^{2+}$ ions and present as silanol groups in the $\mathrm{M}-\mathrm{S}-\mathrm{H}$ between $750^{\circ} \mathrm{C}$ to $208840^{\circ} \mathrm{C}$. A clear relation between bound water and the magnesium content can be 209 observed. 


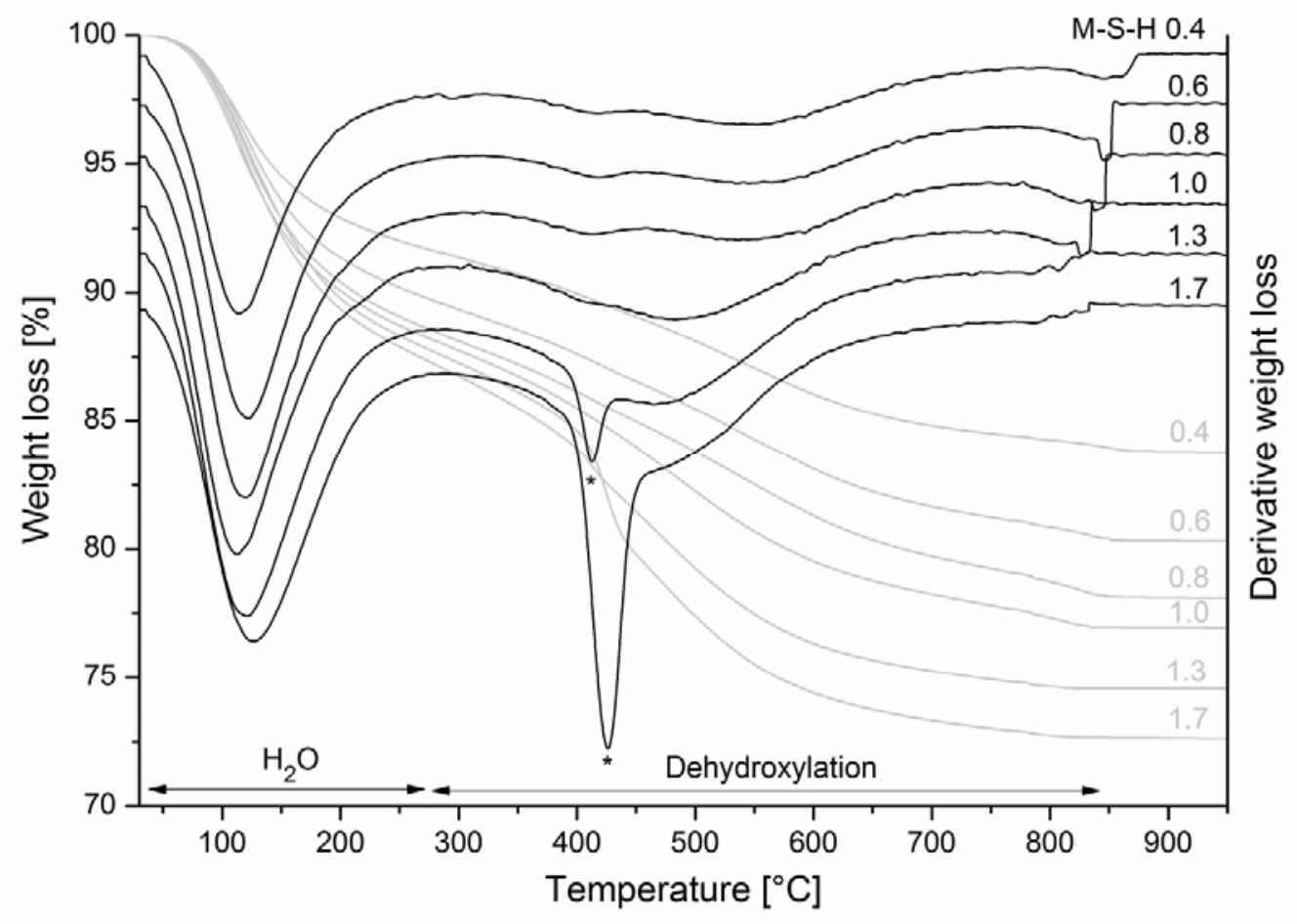

211 Figure 2: Thermogravimetric analysis of the synthesised M-S-H samples with varying $212 \mathrm{Mg} / \mathrm{Si}$ ratios. The asterisks indicate the dehydroxylation peak for brucite.

214 The TGA/DTG data reveal, in accordance with the XRD results, the presence of brucite 215 in the samples with $\mathrm{Mg} / \mathrm{Si}$ ratios $\geq 1.3$, as observed by the well-defined weight loss at $216410^{\circ} \mathrm{C}$ related to the dehydroxylation of $\mathrm{Mg}(\mathrm{OH})_{2}$ to $\mathrm{MgO}$ and $\mathrm{H}_{2} \mathrm{O}$. This result indicates 217 an upper limit of the $\mathrm{Mg} / \mathrm{Si}$ molar ratio in $\mathrm{M}-\mathrm{S}-\mathrm{H}$ equilibrated for 1 year which is close to 218 1.3. The molar fraction of magnesium present in brucite was quantified to be $4 \%$ and $21920 \%$ for the samples with $\mathrm{Mg} / \mathrm{Si}$ ratios of 1.3 and 1.7 , respectively. 
221 Differential thermal analysis (DTA) of the M-S-H samples reveals a distinct exothermic 222 transition around $840-860{ }^{\circ} \mathrm{C}$, which is attributed to the decomposition of amorphous $223 \mathrm{M}-\mathrm{S}-\mathrm{H}$ and the recrystallization to $\mathrm{SiO}_{2}$ and enstatite $\left(\mathrm{MgSiO}_{3}\right)[11,12]$ or $\mathrm{SiO}_{2}$ and 224 forsterite $\left(\mathrm{Mg}_{2} \mathrm{SiO}_{4}\right)$ for high $\mathrm{Mg} / \mathrm{Si}$ ratios [29]. The dehydroxylation of the phyllosilicate 225 sheets in talc $\left(\mathrm{Mg}_{3} \mathrm{Si}_{4} \mathrm{O}_{10}(\mathrm{OH})_{2}\right)$ and the transformation to $\mathrm{SiO}_{2}$ and enstatite occurs at 226 slightly higher temperatures of 850 to $950{ }^{\circ} \mathrm{C}[11,12]$. The lower dehydroxylation 227 temperature of M-S-H compared to talc is consistent with a less crystalline structure [11, 228 12]

\subsubsection{FT-IR and Raman spectroscopy}

231 In accordance with the results from XRD and TGA analyses, the FT-IR spectra 232 (Figure 3) reveal the presence of brucite by the sharp band at $3692 \mathrm{~cm}^{-1}$ [30] in the samples with $\mathrm{Mg} / \mathrm{Si}$ ratios of 1.3 and 1.7. Additionally, the bands at 800,1090 (shoulder) and $1190 \mathrm{~cm}^{-1}$ (shoulder) for the samples with $\mathrm{Mg} / \mathrm{Si}$ molar ratios $\leq 0.8$ are assigned to unreacted silica gel [31]. Furthermore, very weak bands from $\mathrm{CO}_{3}{ }^{2-}$ ions are observed in

236 the range $1400-1500 \mathrm{~cm}^{-1}$ and at $875 \mathrm{~cm}^{-1}$ (this is most pronounced for the samples 237 containing free brucite) $[32,33]$. Generally, the IR spectra of the samples show bands 238 related to $\mathrm{M}-\mathrm{S}-\mathrm{H}$ between $800-1200 \mathrm{~cm}^{-1}$, originating from asymmetric and symmetric 239 Si-O stretching vibrations, and a band at around $665 \mathrm{~cm}^{-1}$, corresponding to Si-O-Si 240 bending vibrations [33]. In all samples a band with increasing intensity for increasing $241 \mathrm{Mg} / \mathrm{Si}$ ratios is observed around $1635 \mathrm{~cm}^{-1}$ which is attributed to $\mathrm{H}-\mathrm{O}-\mathrm{H}$ bending 242 vibrations of molecular bound $\mathrm{H}_{2} \mathrm{O}$. There is a small shift to lower wavenumbers with 243 increasing $\mathrm{Mg} / \mathrm{Si}$ ratios for the main band due to Si-O vibrations of the $\mathrm{Q}^{3}$ tetrahedra at 
$244950-1100 \mathrm{~cm}^{-1}$. The intensity of the $870-920 \mathrm{~cm}^{-1}$ band, related to Si-O vibrations of $\mathrm{Q}^{2}$ 245 tetrahedra, increases with increasing $\mathrm{Mg} / \mathrm{Si}$ ratio. Both observations point towards a 246 stepwise depolymerisation of the silicate network with increasing $\mathrm{Mg} / \mathrm{Si}$ ratio. A 247 systematic decrease in intensity of the band related to Si-O-Si bending at $\sim 665 \mathrm{~cm}^{-1}$ is 248 observed in the order $\mathrm{Mg} / \mathrm{Si}: 1.0>0.8$ and $1.3>1.7$ and $0.6>0.4$, which is most likely 249 attributed to a simple dilution effect of M-S-H caused by the presence of brucite and 250 silica. The band at $3678 \mathrm{~cm}^{-1}$ (shoulder for samples with Mg/Si ratio of 1.3 and 1.7; see 251 inset in Figure 3) is assigned to $\mathrm{OH}$ stretching of $\mathrm{M}-\mathrm{S}-\mathrm{H}$.

252 The band at $3678 \mathrm{~cm}^{-1}$ and the main bands from Si-O stretching and $\mathrm{Si}-\mathrm{O}-\mathrm{Si}$ bending 253 (M-S-H 0.8: 1005 and $662 \mathrm{~cm}^{-1}$, respectively) are in excellent agreement with the 254 vibrational modes observed for the mineral talc $\left(3677,1018\right.$ and $670 \mathrm{~cm}^{-1}$ [34]), 255 indicating a structural similarity of M-S-H and talc. However, these bands could be also 256 indicative for a sepiolite-like structure, as it has been proposed by Gunnarsson et al. 257 [35], or at higher Mg/Si also for serpentine like antigorite $\left(3700,990\right.$ and $620 \mathrm{~cm}^{-1}$ [36]). 


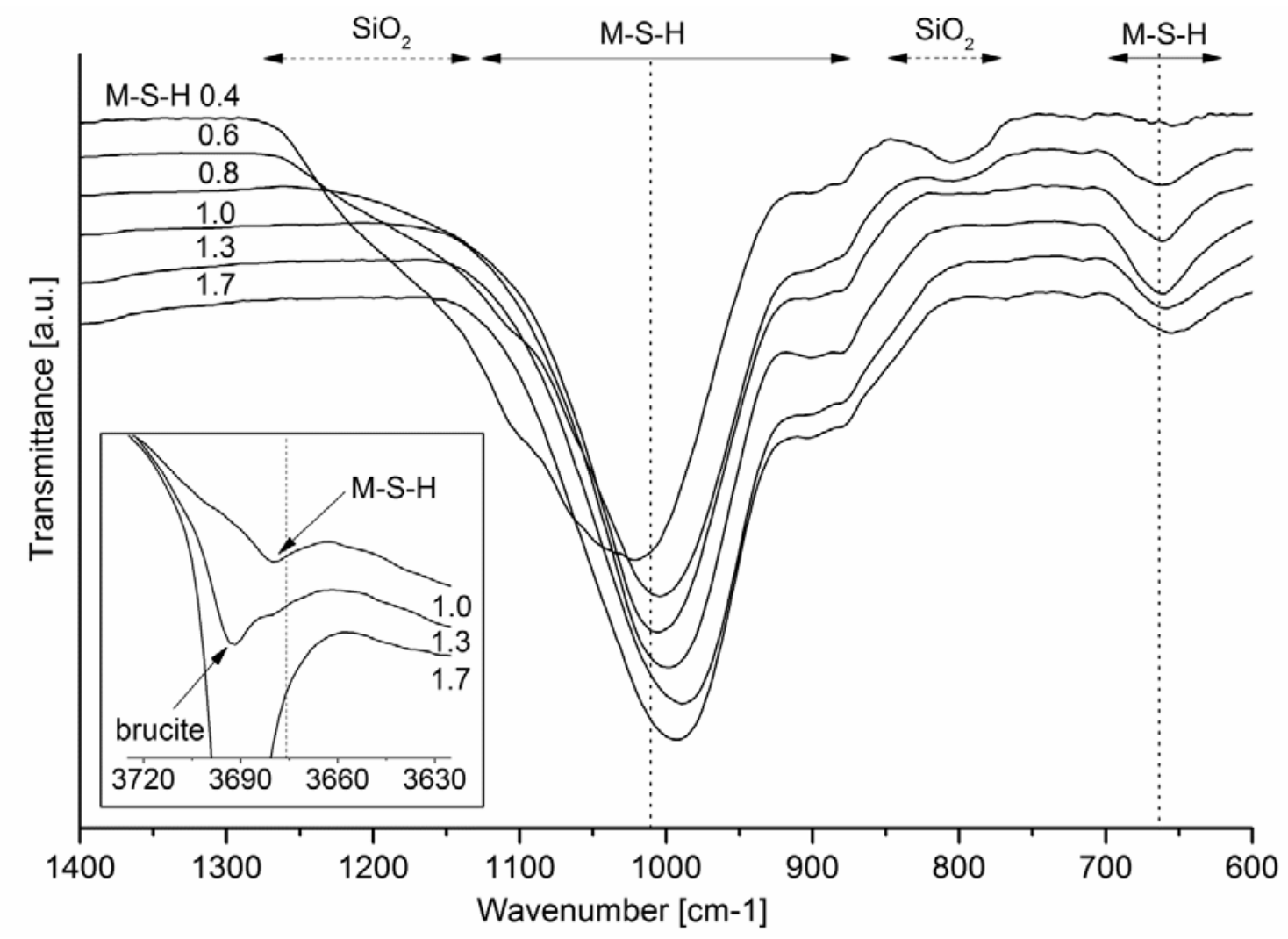

260 Figure 3: FT-IR spectra of the synthetic M-S-H samples with varying Mg/Si ratios. The 261 spectra were scaled to ease comparison. The dotted lines indicate the infrared bands 262 for the mineral talc.

264 In accordance with the XRD and FT-IR results, the Raman spectra (Figure 4) of the 265 M-S-H samples with $\mathrm{Mg} / \mathrm{Si} \geq 1.3$ show bands characteristic for brucite at 270,436 and $2663651 \mathrm{~cm}^{-1}$ (high wavenumber region not shown) [37]. Furthermore, samples with $267 \mathrm{Mg} / \mathrm{Si} \leq 0.6$ show Raman bands at $500 \mathrm{~cm}^{-1}$ and a broad band from 900 to $1550 \mathrm{~cm}^{-1}$ 268 resulting from unreacted silica. Seven major bands, visible in all investigated samples 269 and located at $175,220,361,439,668,882$ and $3686 \mathrm{~cm}^{-1}$, are assigned to 
$270 \mathrm{M}-\mathrm{S}-\mathrm{H}$. These bands are all in reasonable agreement with Raman spectra of the mineral 271 talc $\left(197,232,366,435,456,471,679,795\right.$ and $3675 \mathrm{~cm}^{-1}$ [34]) at lower Mg/Si ratios or 272 minerals from the serpentine group (chrysotile, antigorite or lizardite) [38] and the 273 smectite-class (hectorite) [39]. The position of the typical bands of antigorite $(230,375$, $274520,683,795$ and $1044 \mathrm{~cm}^{-1}$ [38]) show a reasonably good agreement with high-Mg/Si 275 M-S-H. However, due to the broad Raman bands of poorly ordered M-S-H the bands 276 could also be related to chrysotile and lizardite [38] as proposed by Walling et al. [27]. 277 The peaks for M-S-H 0.4 are broader and at slightly higher wavenumbers, which could 278 be related to a poorer ordering and possibly to a different local ordering of the M-S-H. In 279 general, the Raman peaks of M-S-H show a distinct redshift, i.e. they are shifted to 280 lower wavenumbers compared to the crystalline talc or antigorite peaks. Such a redshift 281 could be explained by small particle sizes in the $\mathrm{nm}$ range compared to bulk crystalline 282 material as detailed in [16] for $\mathrm{SiO}_{2}$ nanoparticles. The Raman spectra indicate that two 283 different M-S-H structures are present in $\mathrm{M}-\mathrm{S}-\mathrm{H}$, a low- and a high-Mg/Si M-S-H, both 284 with a phyllosilicate-like structure. 


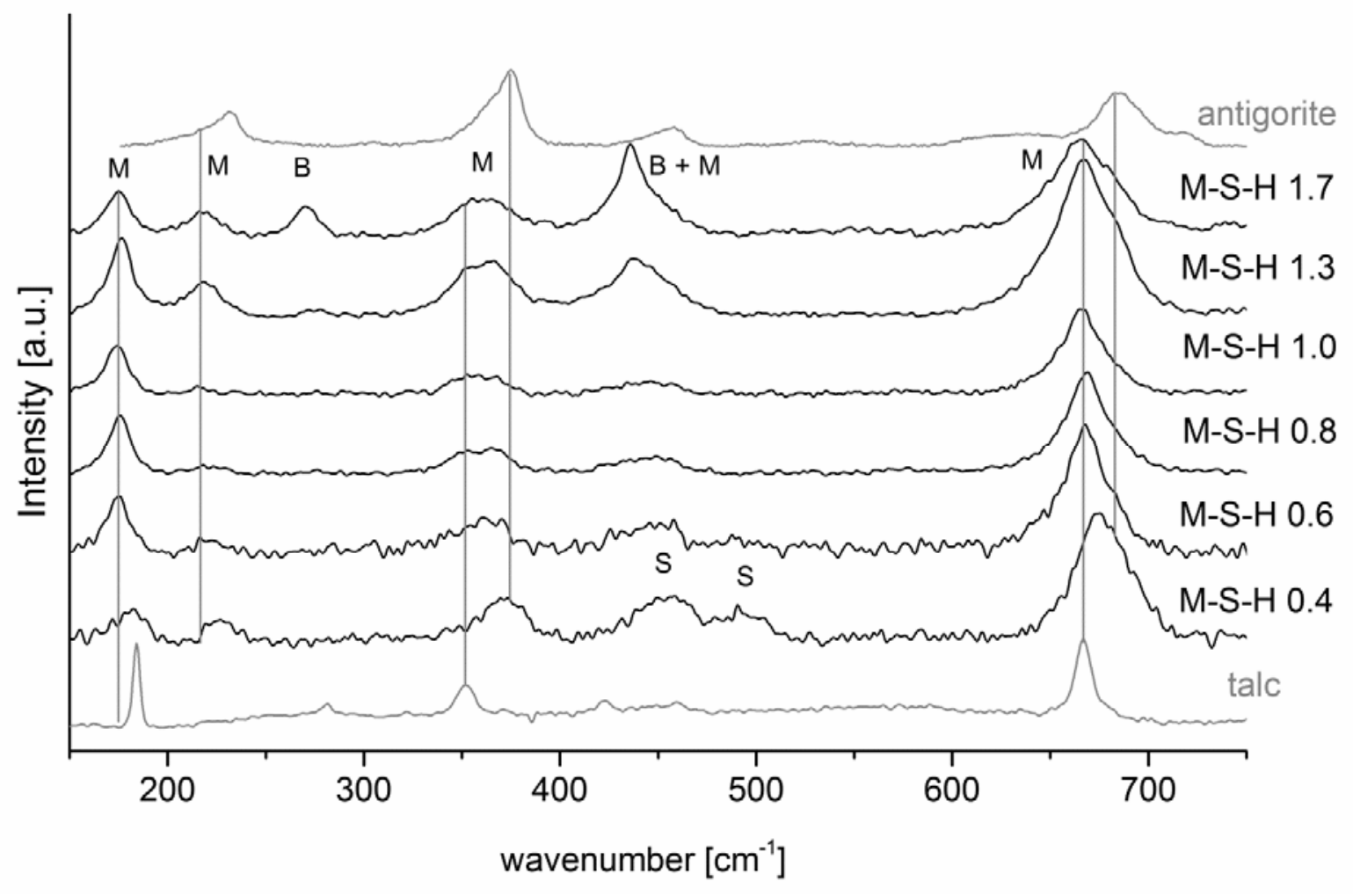

286 Figure 4: Raman spectra of the synthetic M-S-H samples with varying $\mathrm{Mg} / \mathrm{Si}$ ratios and 287 for comparison spectra of talc and antigorite. B: brucite; M: M-S-H; S: unreacted $\mathrm{SiO}_{2}$.

\subsubsection{NMR spectroscopy}

290 The ${ }^{29}$ Si MAS NMR spectra of the M-S-H samples (Figure 5) contain resonances in the 291 range $-78 \mathrm{ppm}$ to $-98 \mathrm{ppm}$, which are assigned to the $\mathrm{M}-\mathrm{S}-\mathrm{H}$ phase. In addition, two broadened peaks at roughly $-101 \mathrm{ppm}$ and $-111 \mathrm{ppm}$ are observed for the $\mathrm{M}-\mathrm{S}-\mathrm{H} 0.4$ 293 and M-S-H 0.6 samples, which reflect the presence of unreacted silica in the form of 294 silica surface sites, $(\mathrm{SiO})_{3} \mathrm{Si}^{*}-\mathrm{OH}$, and fully condensed $(\mathrm{SiO})_{4} \mathrm{Si}^{*}$ sites, respectively, 295 following earlier ${ }^{29}$ Si MAS and CP/MAS NMR studies of silica gels [40]. This assignment 296 is supported by ${ }^{29} \mathrm{Si}\left\{{ }^{1} \mathrm{H}\right\}$ CP/MAS NMR spectra of the M-S-H 0.4 sample (Figure 6), 
where the peak at $-102 \mathrm{ppm}$ is clearly observed whereas the $-111 \mathrm{ppm}$ resonance is

298 absent. A small amount of unreacted silica is also observed for the M-S-H 0.8 sample, which accounts for $4.7 \%$ of the total ${ }^{29} \mathrm{Si} \mathrm{NMR}$ intensity. This indicates that the lower $\mathrm{Mg} / \mathrm{Si}$ limit in M-S-H is $\sim 0.8$, as also observed by the IR spectra (Figure 3 ). The narrow resonance at -85.4 ppm originates from a $\mathrm{Q}^{2}$ site with a chemical shift close to the value for a similar $\mathrm{Q}^{2}$ site in enstatite $\left(\mathrm{MgSiO}_{3}, \delta\left({ }^{29} \mathrm{Si}\right)=-83 \mathrm{ppm}[41]\right)$. The low-intensity peak at -78 ppm is observed at $7 \mathrm{ppm}$ to higher frequency compared to the $\mathrm{Q}^{2}$ resonance, which is a characteristic shift for a lowering in the degree of silicate polymerization [42], and thus, this peak is ascribed to a $Q^{1}$ site. Three overlapping resonances at lower 306 frequency are also observed, with chemical shifts of $-92.4 \mathrm{ppm}$, 307 -94.6 ppm, and -96.7 ppm, which are assigned to three different $\mathrm{Q}^{3}$ sites. These 308 chemical shifts are similar to the value, $\delta\left({ }^{29} \mathrm{Si}\right)=-97.0 \mathrm{ppm}$, reported for crystalline talc 309 [43] and the value of $-93.1 \mathrm{ppm}$ reported for antigorite [44], indicating the presence of a 310 silicate sheet structure The observed broad $Q^{3}$ signal could be explained by structural 311 deformations as discussed in [10]. Alternatively, the $Q^{3}$ sites may reflect branching 312 silicate chain sites, as observed in xonotlite (-97.8 ppm [42]) as well as $9 \AA$ - and $11 \AA$ 313 tobermorites (-96.4 to $-97.8 \mathrm{ppm}[45])$. The three $\mathrm{Q}^{3}$ sites contain $63-70 \%$ of the total 314 intensity for the $\mathrm{Mg} / \mathrm{Si}=0.4-0.8$ samples, when the contribution from the silica gel is 315 disregarded, whereas their intensity decrease from $55 \%$ to $40 \%$ for the $\mathrm{Mg} / \mathrm{Si}=1.0-1.7$ 316 M-S-H phases. This observation strongly suggests that silicate sheets are a principal 317 constituent of the M-S-H structures. ${ }^{29} \mathrm{Si}\left\{{ }^{1} \mathrm{H}\right\}$ CP/MAS NMR spectra of the M-S-H 1.0 318 sample (Figure 6) show that all resonances associated with the M-S-H phase originate 319 from Si sites with hydrogen in their near vicinity (i.e., within the second or third 
coordination spheres). Comparison of the spectra acquired with different CP contact times $\left(\tau_{\mathrm{CP}}\right)$ reveal a stronger ${ }^{1} \mathrm{H}-{ }^{29} \mathrm{Si} \mathrm{CP}$ intensity enhancement for the $\mathrm{Q}^{1}$ and $\mathrm{Q}^{2}$ sites at low $\mathrm{CP}$ contact times relative to the $\mathrm{Q}^{3}$ sites, for which the largest $\mathrm{CP}$ transfer appears at longer contact time $\left(\tau_{\mathrm{CP}} \geq 5.0 \mathrm{~ms}\right)$. These observations strongly suggest that the $\mathrm{Q}^{1}$ and $\mathrm{Q}^{2}$ sites include hydroxyl groups, $\mathrm{Si}-\mathrm{O}-\mathrm{Si}^{*}-\mathrm{OH}$ and $(\mathrm{Si}-\mathrm{O})_{2}-\mathrm{Si}{ }^{*}-\mathrm{OH}$ sites, respectively, whereas ${ }^{1} \mathrm{H}$ is present in further distant coordination spheres for the silicons in the $\mathrm{Q}^{3}$ sheets, e.g., hydroxyl groups bonded to $\mathrm{Mg}^{2+}$ ions or interlayer water molecules. The presence of hydroxyl groups bonded to $\mathrm{Mg}$ is also found in the structures for talc, antigorite and other phyllosilicates.

The single-pulse ${ }^{29}$ Si MAS NMR spectra (Figure 5) have been deconvolved, employing resonances for the different ${ }^{29} \mathrm{Si}$ sites mentioned above, as illustrated for the spectrum of the M-S-H 0.6 sample in Figure 7. The relative intensities from the deconvolutions are listed in Table 2 along with the calculated $Q^{3} / Q^{2}$ ratios for the $M-S-H$ phases. At $\mathrm{Mg} / \mathrm{Si} \leq 0.8$ a $\mathrm{Q}^{3} / \mathrm{Q}^{2}$ ratio of $\approx 2$ (Table 2 ) is observed. This ratio decreases with increasing Mg/Si content. Talc and antigorite exhibit sheet structures, corresponding to $\mathrm{Q}^{3} / \mathrm{Q}^{2}>$, whereas a triple-chains structure of $\mathrm{SiO}_{4}$ tetrahedra, such as found in jimthompsonite, would have a ratio $Q^{3} / Q^{2}=2$ at infinite chain length. Smaller values for $Q^{3} / Q^{2}$ may reflect a conversion of the triple chains into double chains, where some of the Si-O-Si bonds of the branching tetrahedra are broken. For example, a double-chain structure where the Si-O-Si bond in every second branching site is broken will have the ratio $Q^{3} / Q^{2}=0.50$, as found in the xonotlite $\left(\mathrm{Ca}_{6} \mathrm{Si}_{6} \mathrm{O}_{17}(\mathrm{OH})_{2}\right)$. Alternatively very small coherent regions of sheet silicates could result in a high fraction of $Q^{2}$ units at the edge of the silica sheets and thus, $Q^{3} / Q^{2}=2$ could be obtained as recently suggested by 
343 Roosz et al. [10]. It is apparent from both the XRD analysis and the ${ }^{29} \mathrm{Si} \mathrm{NMR} \mathrm{spectra}$ 344 that the M-S-H samples are not highly ordered and the clear observation of a significant 345 fraction of $Q^{1}$ sites (Table 2) reflect a disordered structure with several vacancies or 346 broken chains in the polymerized silicate network. An overall layer structure, where the 347 silicate sheets are connected by layers of octahedrally coordinated $\mathrm{Mg}^{2+}$ ions and similar 348 to the structure of talc, antigorite or jimthompsonite, will also imply that the $Q^{3}$ sites are 349 further distant from hydroxyl groups than the $Q^{2}$ and $Q^{1}$ sites, associated with the 350 defects mentioned above. Thus, the ${ }^{29} \mathrm{Si}\left\{{ }^{1} \mathrm{H}\right\} \mathrm{CP} / \mathrm{MAS}$ NMR spectra support this model 351 since optimum CP transfer is observed for short CP contact time for the $Q^{1}$ and $Q^{2}$ sites 352 and longer times for the $\mathrm{Q}^{3}$ sites, reflecting these are further distant from the hydroxyl 353 groups. In talc, antigorite and jimpthompsonite all hydroxyl groups are bonded to $\mathrm{Mg}^{2+}$ 354 ions which would result in long optimum ${ }^{1} \mathrm{H}-{ }^{29} \mathrm{Si} \mathrm{CP}$ contact times, considering that the $355{ }^{1} \mathrm{H}-{ }^{29} \mathrm{Si}$ dipolar interaction is inversely proportional to the cube of the internuclear 356 distance. 


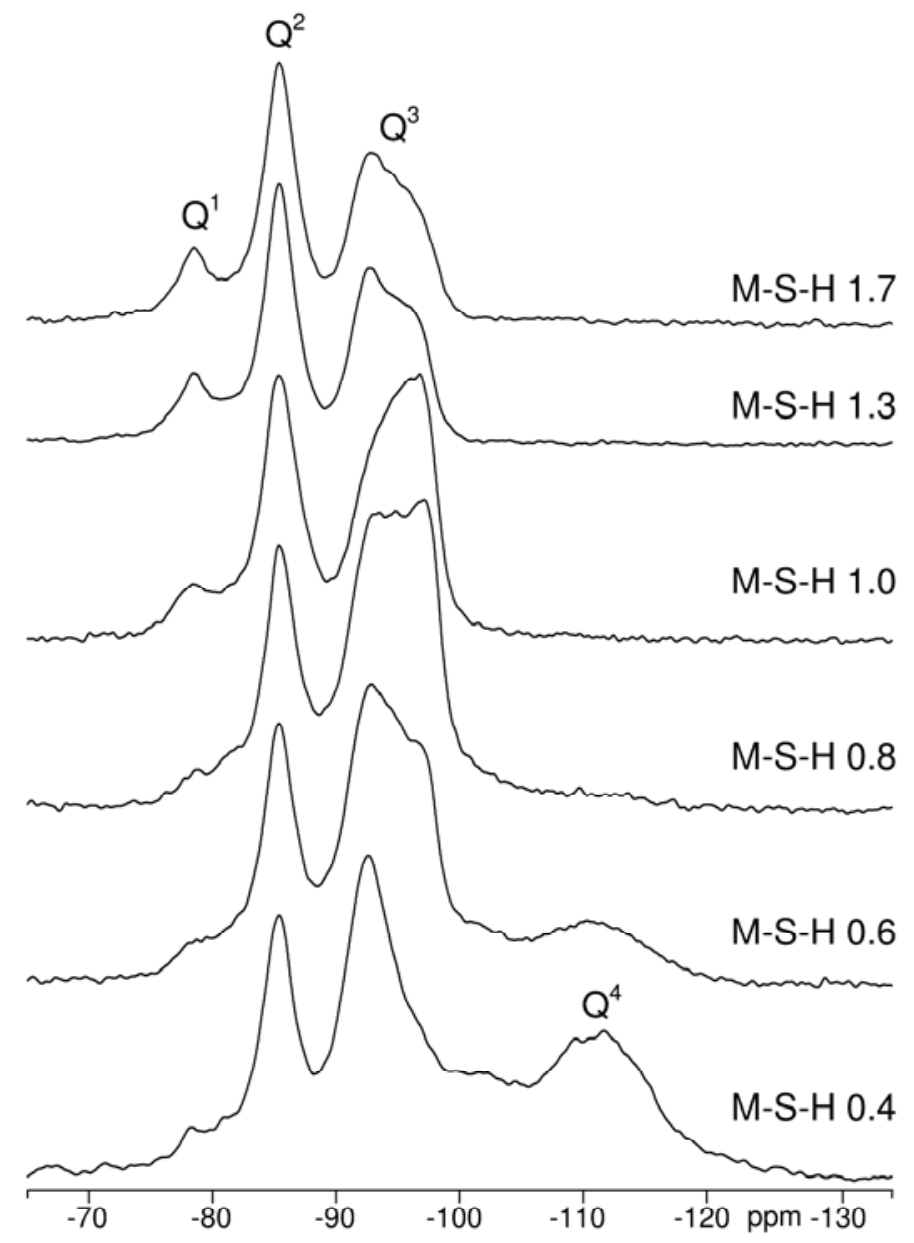

358 Figure $5 .{ }^{29} \mathrm{Si}$ MAS NMR spectra $\left(9.4 \mathrm{~T}, v_{\mathrm{R}}=4.5 \mathrm{kHz}\right)$ of the synthesized $\mathrm{M}-\mathrm{S}-\mathrm{H}$ 359 samples with $\mathrm{Mg} / \mathrm{Si}$ ratios ranging from 0.4 to 1.7 .

360 


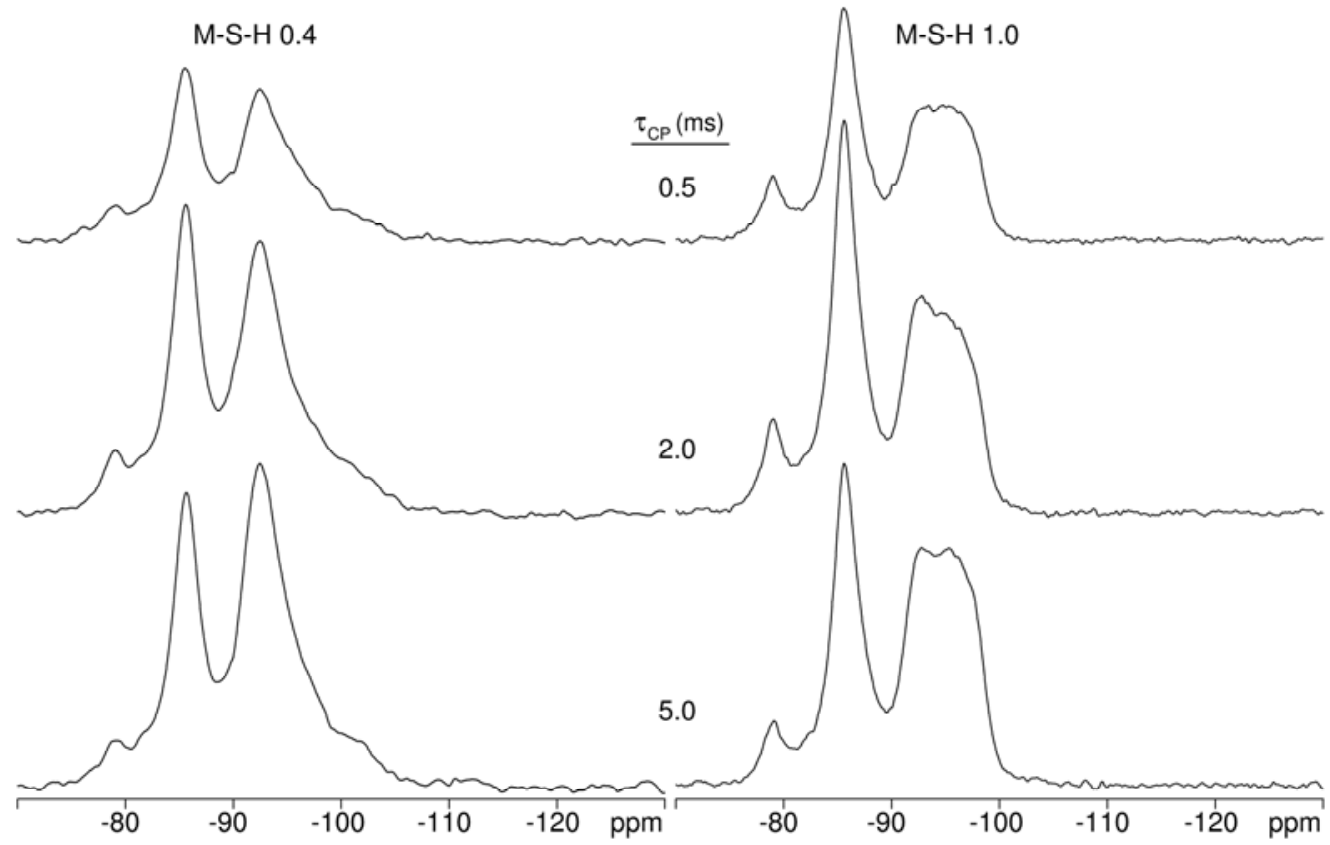

362 Figure $6 .{ }^{29} \mathrm{Si}\left\{{ }^{1} \mathrm{H}\right\}$ CP/MAS NMR spectra $\left(9.4 \mathrm{~T}, v_{\mathrm{R}}=4.0 \mathrm{kHz}\right)$ of the M-S-H 0.4 and 363 M-S-H 1.0 samples acquired with three different CP contact times $\left(\tau_{\mathrm{CP}}\right)$. The spectra for 364 the two samples are shown on identical vertical scale. 

the M-S-H phases.

\begin{tabular}{|c|c|c|c|c|c|c|c|c|}
\hline \multirow{3}{*}{$\begin{array}{l}\text { initial } \\
\mathrm{Mg} / \mathrm{Si}\end{array}$} & \multicolumn{7}{|c|}{${ }^{29}$ Si chemical shifts - ppm (relative peak intensities - \%) } & \multirow{3}{*}{$\mathbf{Q}^{3} / \mathbf{Q}^{2(*)}$} \\
\hline & \multicolumn{5}{|c|}{ M-S-H } & \multicolumn{2}{|c|}{ unreacted $\mathrm{SiO}_{2}$} & \\
\hline & $\mathbf{Q}^{1}$ & $\mathbf{Q}^{2}$ & $\mathbf{Q}^{3 \mathbf{a}}$ & $\mathbf{Q}^{3 \mathbf{b}}$ & $\mathbf{Q}^{3 c}$ & $\mathbf{Q}^{3}$ & $\mathbf{Q}^{4}$ & \\
\hline 0.4 & $-78.3(1.3)$ & $-85.4(21.6)$ & $-92.4(23.9)$ & $-94.6(8.1)$ & $-96.7(7.1)$ & $-100.9(7.8)$ & $-110.7(30.1)$ & 1.78 \\
\hline 0.6 & $-78.3(3.3)$ & $-85.4(22.6)$ & $-92.4(25.5)$ & $-94.6(19.2)$ & $-96.7(10.0)$ & $-100.9(4.6)$ & $-110.7(14.7)$ & 2.39 \\
\hline 0.8 & $-78.3(3.2)$ & $-85.4(25.9)$ & $-92.4(29.3)$ & $-94.6(14.8)$ & $-96.7(22.1)$ & $-100.9(1.1)$ & $-110.7(3.6)$ & 2.54 \\
\hline 1.0 & $-78.3(4.5)$ & $-85.4(40.8)$ & $-92.4(15.2)$ & $-94.6(25.7)$ & $-96.7(13.8)$ & - & - & 1.34 \\
\hline 1.3 & $\begin{array}{l}-78.3 \\
(12.5)\end{array}$ & $-85.4(44.2)$ & $-92.4(22.6)$ & $-94.6(7.8)$ & $-96.7(13.0)$ & - & - & 0.98 \\
\hline 1.7 & $\begin{array}{c}-78.3 \\
(11.7)\end{array}$ & $-85.4(48.1)$ & $-92.4(18.5)$ & $-94.6(10.9)$ & $-96.7(10.7)$ & - & - & 0.84 \\
\hline
\end{tabular}

\footnotetext{
${ }^{(*)}$ Calculated $Q^{3} / Q^{2}$ ratio, $I\left(Q^{3}\right) /\left(Q^{2}\right)$ for the M-S-H where $I\left(Q^{3}\right)=I\left(Q^{3 a}\right)+I\left(Q^{3 b}\right)+I\left(Q^{3 c}\right)$.
} 


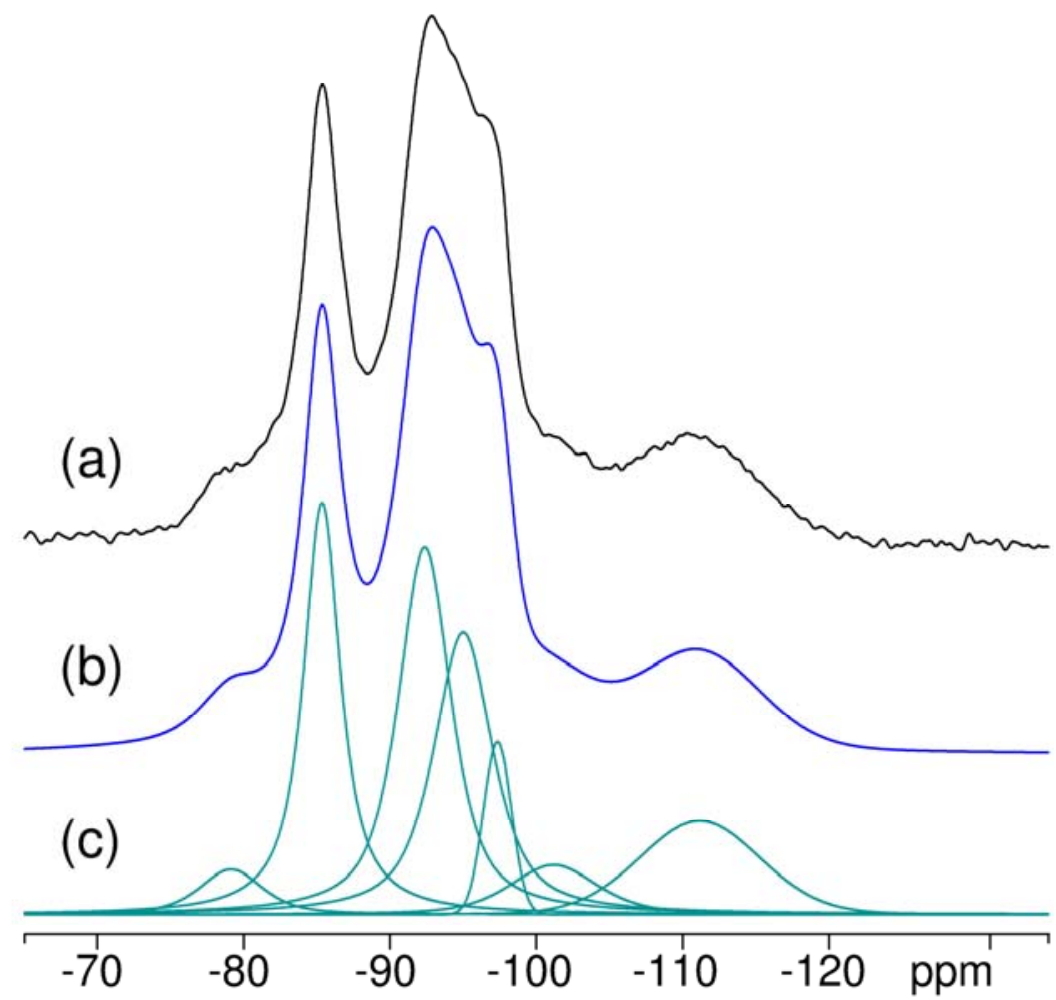

368

369 Figure 7. (a) ${ }^{29} \mathrm{Si}$ MAS NMR spectrum $\left(9.4 \mathrm{~T}, v_{\mathrm{R}}=4.5 \mathrm{kHz}\right)$ of the M-S-H 0.6 and (b) the 370 optimum deconvolution, employing the peaks shown in part (c), which exhibit the 371 intensities listed in Table 2. 


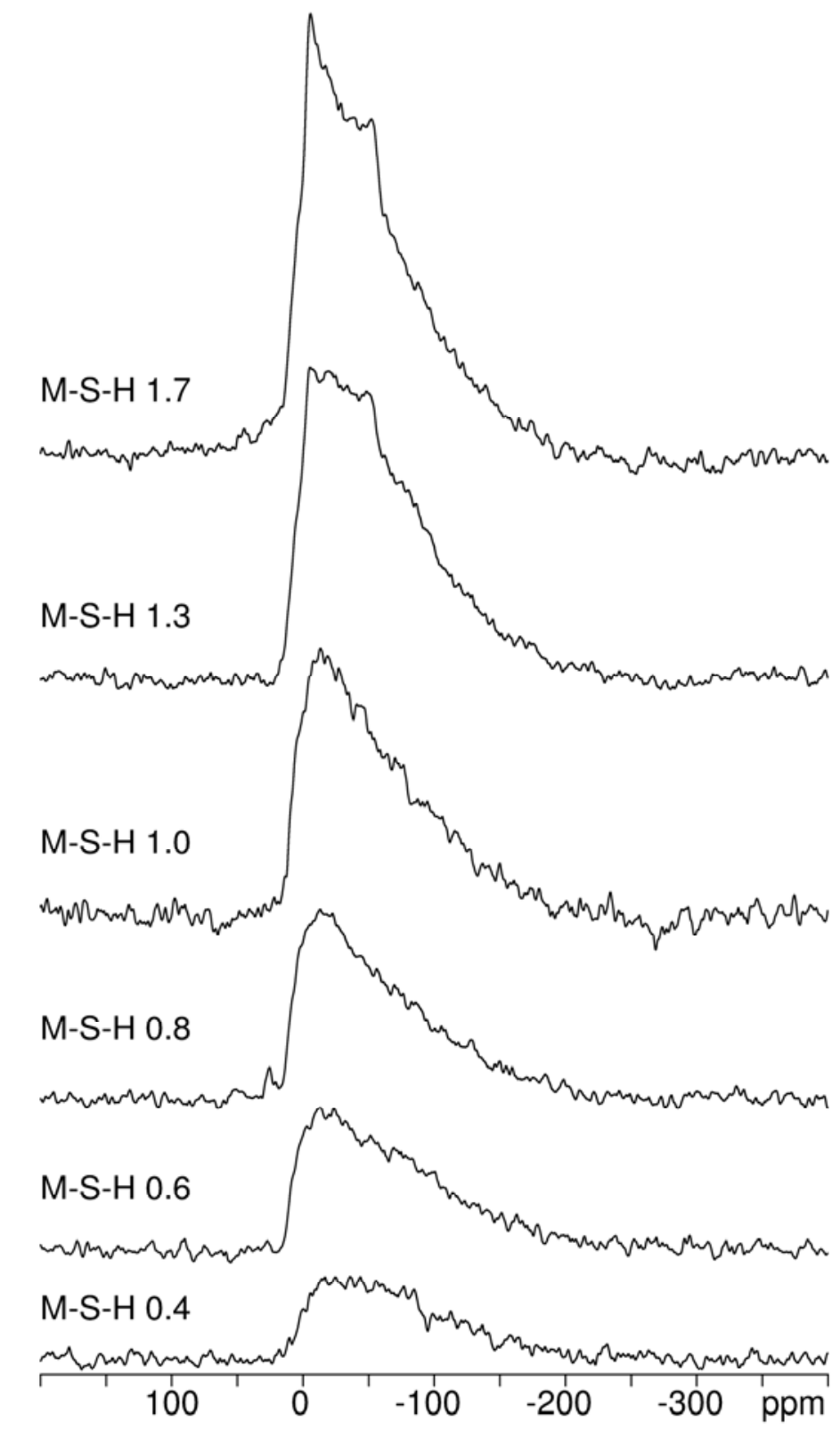

373 Figure 8. Spin-echo ${ }^{25} \mathrm{Mg}$ MAS NMR spectra $\left(14.1 \mathrm{~T}, v_{\mathrm{R}}=12.0 \mathrm{kHz}\right)$ of the $\mathrm{M}-\mathrm{S}-\mathrm{H}$ 374 samples shown on identical intensity scales. 

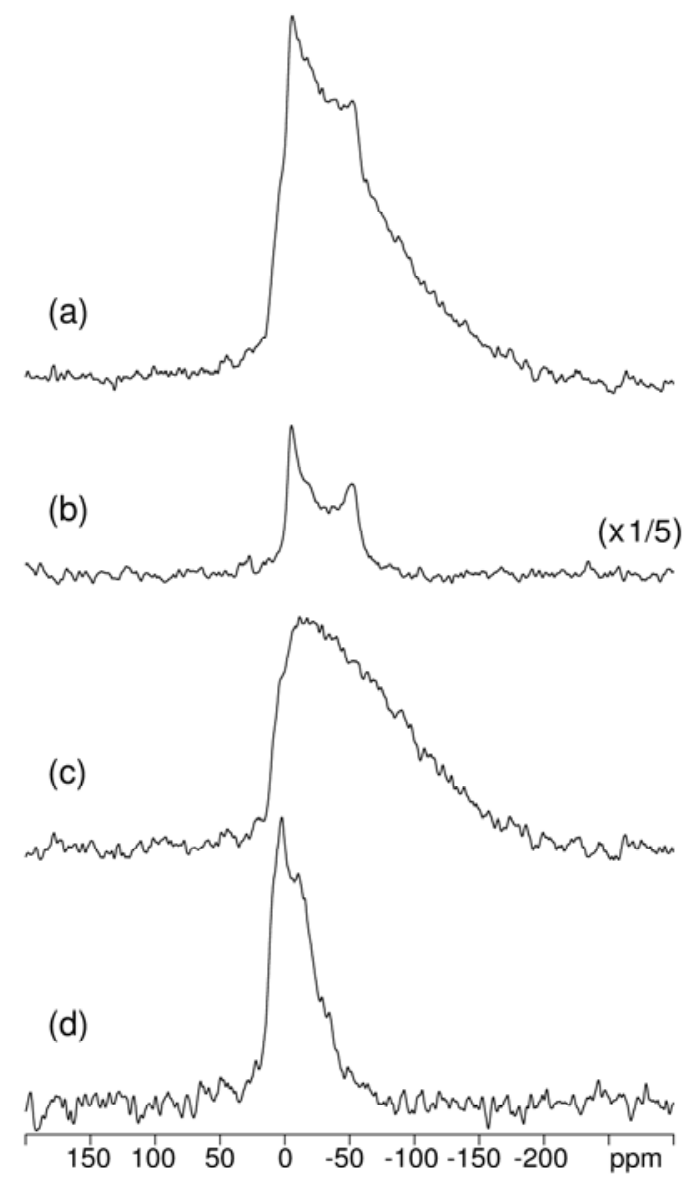

376 Figure 9. Spin-echo ${ }^{25} \mathrm{Mg}$ MAS NMR spectra (14.1 T, $v_{R}=12.0 \mathrm{kHz}$ ) of (a) M-S-H 1.7, (b) $377 \mathrm{Mg}(\mathrm{OH})_{2}$ and (d) a mineral sample of talc. Subtraction of the $\mathrm{Mg}(\mathrm{OH})_{2}$ spectrum from the 378 spectrum of $\mathrm{M}-\mathrm{S}-\mathrm{H} 1.7$, using a scaling factor of $1 / 5$ for $\mathrm{Mg}(\mathrm{OH})_{2}$, as used in part 379 (b),gives the difference spectrum shown in part (c).

381 Spin-echo ${ }^{25} \mathrm{Mg}$ MAS NMR spectra of the M-S-H samples, obtained with ${ }^{1} \mathrm{H}$ decoupling 382 during both the evolution and detection periods (Figure 8), all include a broadened 
asymmetric centerband resonance ranging from roughly $0 \mathrm{ppm}$ to $-250 \mathrm{ppm}$, which intensity increases with increasing $\mathrm{Mg} / \mathrm{Si}$ ratio. Indications of distinct peaks at $-5 \mathrm{ppm}$ and $-52 \mathrm{ppm}$ are observed in the lineshapes for the M-S-H 1.3 and 1.7 samples. The XRD analysis showed that these samples contain a small amount of $\mathrm{Mg}(\mathrm{OH})_{2}$ and thus, the ${ }^{25} \mathrm{Mg}$ MAS NMR spectra of M-S-H 1.7 and a pure sample of $\mathrm{Mg}(\mathrm{OH})_{2}$ are compared in Figure 9. The ${ }^{25} \mathrm{Mg}$ MAS NMR spectrum of $\mathrm{Mg}(\mathrm{OH})_{2}$ show the characteristic features of second-order quadrupolar lineshape for a single ${ }^{25} \mathrm{Mg}$ site. Simulation of this lineshape results in the isotropic chemical shift, $\delta_{\text {iso }}\left({ }^{25} \mathrm{Mg}\right)=10.0 \mathrm{ppm}$, and the quadrupole coupling parameters, $C_{Q}=3.08 \mathrm{MHz}$ and $\eta_{\mathrm{Q}}=0.0$, in good agreement with earlier reported values [46] and the crystal structure for brucite [47]. Moreover, the two singularities of the quadrupolar lineshape match the peaks observed in the ${ }^{25} \mathrm{Mg}$ MAS NMR spectra of M-S-H 1.3 and M-S-H 1.7. TGA indicated that the M-S-H 1.7 sample contains 20 wt. $\% \mathrm{Mg}(\mathrm{OH})_{2}$ and subtraction of the experimental ${ }^{25} \mathrm{Mg}$ NMR spectrum of $\mathrm{Mg}(\mathrm{OH})_{2}$ from the spectrum of $\mathrm{M}-\mathrm{S}-\mathrm{H}$ 1.7, using a scaling factor corresponding a $\mathrm{Mg}(\mathrm{OH})_{2}$ content of $20 \mathrm{wt} \%$, gives the difference spectrum shown in Figure 9c. The asymmetric lineshape in this spectrum resembles the spectra observed for the M-S-H samples with lower $\mathrm{Mg} / \mathrm{Si}$ ratios, thereby indicating that the environments of the $\mathrm{Mg}^{2+}$ ions in the different M-S-H samples are very similar and independent of the $\mathrm{Mg} / \mathrm{Si}$ ratio. Moreover, comparison of ${ }^{25} \mathrm{Mg}$ MAS NMR spectra, acquired with and without ${ }^{1} \mathrm{H}$ decoupling, shows a small line-narrowing effect of ${ }^{1} \mathrm{H}$ decoupling, suggesting the presence of ${ }^{1} \mathrm{H}$ atoms in the near vicinity, either as $\mathrm{Mg}-\mathrm{OH}$ or solid water very close to the Mg layers. Figure 9 also includes a spectrum of a pure mineral sample of talc, which contains a centerband resonance with a much smaller width than those observed for the 
$406 \mathrm{M}-\mathrm{S}-\mathrm{H}$ samples and $\mathrm{Mg}(\mathrm{OH})_{2}$. The asymmetric form of the centerband observed for the 407 M-S-H samples is typical for a distribution in quadrupolar coupling parameters [48, 49], 408 reflecting variation in the local environments for the $\mathrm{Mg}^{2+}$ sites. This agrees well with the 409 disordered nature of the M-S-H phases observed by ${ }^{29} \mathrm{Si}$ NMR.

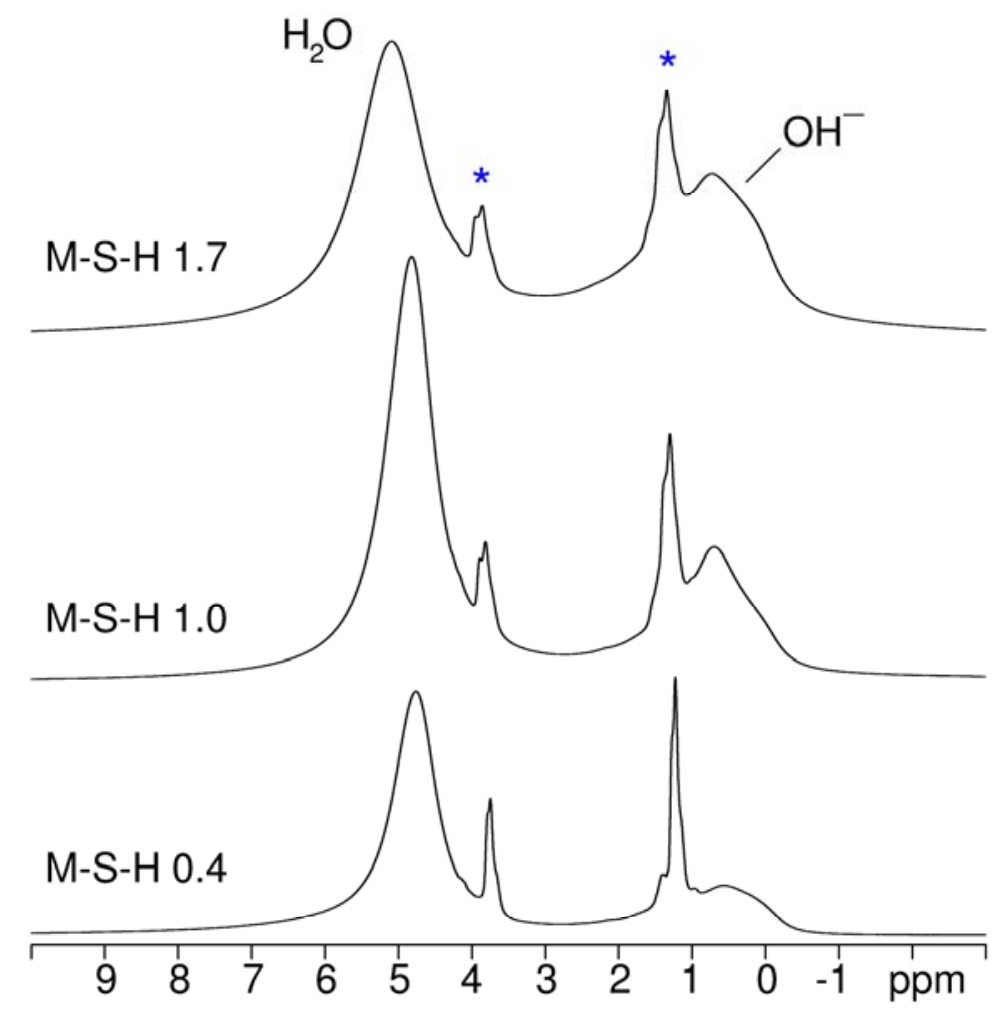

412 Figure 10. ${ }^{1} \mathrm{H}$ MAS NMR spectra $\left(14.1 \mathrm{~T}, v_{\mathrm{R}}=40.0 \mathrm{kHz}\right)$ of three selected M-S-H 413 samples. The asterisks indicate resonances from impurity phases, i.e., the $\mathrm{CH}_{2}$ and $\mathrm{CH}_{3}$ 414 groups of ethanol at 3.8 and 1.3 ppm, respectively.

$415{ }^{1} \mathrm{H}$ MAS NMR spectra, recorded with a high spinning speed $\left(v_{R}=40.0 \mathrm{kHz}\right)$, have be 416 obtained for all M-S-H samples and allow distinction of the resonances from water 
417 molecules in the structure and hydroxyl groups. Selected spectra are shown in Figure 41810 , where the broad resonance at $4.8-5.1 \mathrm{ppm}$ can be assigned to ${ }^{1} \mathrm{H}$ in solid water. A 419 second broad resonance is observed in the range $0-1 \mathrm{ppm}$ with a lineshape that 420 indicate the presence of two overlapping resonances. These resonances originate from 421 hydroxyl groups, potentially two different types of $\mathrm{Mg}-\mathrm{OH}$ sites, considering the ${ }^{1} \mathrm{H}$ 422 chemical shifts of $0.3 \mathrm{ppm}$ and $0.5 \mathrm{ppm}$ observed in similar high-speed ${ }^{1} \mathrm{H}$ MAS NMR 423 experiments for $\mathrm{Mg}(\mathrm{OH})_{2}$ and the talc sample, respectively, in accordance with literature 424 values for these samples $[50,51]$. In addition, two narrow resonances at 3.8 and 1.8 425 ppm are present in all spectra (Figure 10). These peaks are ascribed to the $\mathrm{CH}_{2}$ and $426 \mathrm{CH}_{3}$ groups of ethanol or ethoxy groups bonded to the M-S-H structure, and reflecting 427 that the samples have been washed with ethanol prior to drying. The ${ }^{1} \mathrm{H}$ MAS NMR 428 spectra have been deconvolved using resonances for water, the hydroxyl groups, and $429{ }^{1} \mathrm{H}$ in ethanol, resulting in the relative ${ }^{1} \mathrm{H}$ NMR intensities listed in Table 3 . The molar $430 \mathrm{H}_{2} \mathrm{O} / \mathrm{OH}$ ratios, calculated from these intensities, decrease with increasing $\mathrm{Mg} / \mathrm{Si}$ ratio. 431 We note that these ratios are slightly underestimated since the ${ }^{29} \mathrm{Si}$ NMR and XRD 432 analyses have shown that the M-S-H 0.4 and 0.6 samples contain a small fraction of 433 unreacted silica gel, including $(\mathrm{Si}-\mathrm{O})_{3} \mathrm{Si}-\mathrm{OH}$ sites (Table 2), and that $\mathrm{Mg}(\mathrm{OH})_{2}$ is present 434 as an impurity phase in the M-S-H 1.3 and 1.7 samples. The hydroxyl groups from these 435 additional phases contribute with intensity to the resonance at $0.5-0.7 \mathrm{ppm}$, resulting in 436 a lowering of the molar $\mathrm{H}_{2} \mathrm{O} / \mathrm{OH}$ ratio for the $\mathrm{M}-\mathrm{S}-\mathrm{H}$ phases. 
438 Table $3 .{ }^{1} \mathrm{H}$ chemical shifts and relative intensities of the resonances from water and 439 hydroxyl groups, obtained from ${ }^{1} \mathrm{H}$ MAS NMR spectra of the M-S-H samples, along with 440 the total bound water and molar total water content per silica in M-S-H from TGA.

\begin{tabular}{ccccccccc}
\hline $\mathrm{Mg} / \mathrm{Si}$ & $\begin{array}{c}\delta\left(\mathrm{H}_{2} \mathrm{O}\right) \\
(\mathrm{ppm})\end{array}$ & $\begin{array}{c}\delta(\mathrm{OH}) \\
(\mathrm{ppm})\end{array}$ & $I\left(\mathrm{H}_{2} \mathrm{O}\right)^{\mathrm{a}}$ & $I(\mathrm{OH})^{\mathrm{a}}$ & $\begin{array}{c}\text { Molar } \\
\mathrm{H}_{2} \mathrm{O} / \mathrm{OH}\end{array}$ & $\begin{array}{c}\text { TGA weight } \\
\text { loss (wt. \% })^{\mathrm{b}}\end{array}$ & $\begin{array}{c}\text { Weight } \\
{\text { loss } / \mathrm{Si}^{\mathrm{c}}}^{\mathrm{H}}\end{array}$ & $\begin{array}{c}\mathrm{H}_{2} \mathrm{O} \\
\mathrm{Si}^{\mathrm{d}}\end{array}$ \\
\hline 0.4 & 4.75 & 0.57 & 79.9 & 20.1 & 1.99 & 16.2 & 0.82 & 0.66 \\
0.6 & 4.82 & 0.60 & 77.7 & 22.3 & 1.74 & 19.7 & 1.15 & 0.89 \\
0.8 & 4.85 & 0.72 & 74.2 & 25.8 & 1.44 & 21.9 & 1.44 & 1.07 \\
1.0 & 4.82 & 0.70 & 69.0 & 31.0 & 1.11 & 23.1 & 1.67 & 1.15 \\
1.3 & 5.0 & 0.74 & 68.0 & 32.0 & 1.06 & 24.8 & 2.08 & 1.45 \\
1.7 & 5.10 & 0.74 & 62.6 & 37.4 & 0.84 & 24.6 & 2.42 & 1.69 \\
\hline
\end{tabular}

${ }^{a}$ Relative intensities from deconvolution of the ${ }^{1} \mathrm{H}$ MAS NMR spectra, excluding the

442 contribution from the impurity resonances.

$443{ }^{\mathrm{b}}$ TGA weight loss from 40 to $950^{\circ} \mathrm{C}$ including loosely bound $\mathrm{H}_{2} \mathrm{O}$ and water loss from 444 dehydroxylation of hydroxyl groups.

$445{ }^{\mathrm{c}}$ Weight loss per Si in M-S-H corrected for the presence of brucite (TGA) and unreacted $446 \quad \mathrm{SiO}_{2}(\mathrm{NMR})$.

$447 \quad{ }^{d} \mathrm{H}_{2} \mathrm{O} / \mathrm{Si}=$ weight loss $/ \mathrm{Si} \cdot I\left(\mathrm{H}_{2} \mathrm{O}\right) / 100$;

\subsubsection{M-S-H composition}

450 Based on the TGA and the deconvolution of the ${ }^{29} \mathrm{Si} \mathrm{NMR}$ spectra, the solid Mg/Si molar 451 ratios as well as the total content of hydroxyl groups together with the bound interlayer 452 water of the precipitated M-S-H can be calculated. The values for the $\mathrm{Mg} / \mathrm{Si}$ molar ratios 453 range from 0.7 to 1.5 (see Table 4 for details). Two obvious trends are noticeable with 454 increasing $\mathrm{Mg} / \mathrm{Si}$ ratio in synthetic $\mathrm{M}-\mathrm{S}-\mathrm{H}$ : 
a) an increase in the interlayer water which could possibly be related to the depolymerisation of the silicate network which makes it more hydrophilic and

b) an increase in the number of hydroxyl groups which are most likely bound within the octahedral $\mathrm{MgO}$ sheet and to lesser extend in form of silanol groups.

By comparison of the proposed stoichiometry of the different M-S-H samples (Table 4) with the $Q^{3} / Q^{2}$ silicon environments obtained by NMR (Table 2), the synthesised samples can be divided in three different sets: a) The samples with an initial Mg/Si molar ratio $\leq 0.8, b)$ the $\mathrm{M}-\mathrm{S}-\mathrm{H}$ with an initial $\mathrm{Mg} / \mathrm{Si}$ molar ratio of 1 , and $\mathrm{c}$ ) the $\mathrm{M}-\mathrm{S}-\mathrm{H}$ samples with an initial $\mathrm{Mg} / \mathrm{Si}$ ratio $\geq 1.3$. The first set is characterised by high $\mathrm{Q}^{3} / \mathrm{Q}^{2}$ ratios ranging from 1.78 to 2.54 , similar Mg/Si ratios as well as similar contents of hydroxyl groups and interlayer water. The last set with an initial $\mathrm{Mg} / \mathrm{Si}$ ratio $\geq 1.3$ is comprised of $\mathrm{M}-\mathrm{S}-\mathrm{H}$ with low $\mathrm{Q}^{3} / \mathrm{Q}^{2}$ ratios, i.e. $<1.0$, high $\mathrm{Mg} / \mathrm{Si}$ ratios and high contents of hydroxyl groups and loosely bound water. The data for these solid phase would be consistent with (i) the formation of a M-S-H with a variable composition in the range, $\mathrm{M}_{0.64} \mathrm{SH}_{0.78}$ to $\mathrm{M}_{1.4} \mathrm{SH}_{2.4}$, or (ii) the presence of two immiscible solids $\mathrm{M}_{0.64} \mathrm{SH}_{0.78}$ and $\mathrm{M}_{1.42} \mathrm{SH}_{2.42}$ where both are present at $\mathrm{Mg} / \mathrm{Si}=1$.

Table 4: Summary of the experimentally determined $\mathrm{Mg} / \mathrm{Si}$ molar ratios, content of hydroxyl groups and interlayer water of the synthesised M-S-H.

\begin{tabular}{ccccccc}
\hline $\begin{array}{c}\text { Initial } \\
\mathrm{Mg} / \mathrm{Si}\end{array}$ & $\mathrm{Mg}-\mathrm{S}-\mathrm{H}$ & & & & & \\
& $\mathrm{Si}$ & $\mathrm{H}_{2} \mathrm{O} / \mathrm{Si}^{\mathrm{b}}$ & $\mathrm{Si}-\mathrm{OH} / \mathrm{Si}^{\mathrm{c}}$ & $\mathrm{Mg}-\mathrm{OH} / \mathrm{Si}^{\mathrm{d}}$ & \multicolumn{2}{c}{ composition } \\
\hline 0.4 & 0.64 & 0.66 & 0.24 & 0.01 & $\mathrm{Mg}_{0.64} \mathrm{O}_{0.52}(\mathrm{OH})_{0.25} \mathrm{SiO}_{2} \cdot\left(\mathrm{H}_{2} \mathrm{O}\right)_{0.66}$ & $\mathrm{M}_{0.64} \mathrm{SH}_{0.78}$ \\
0.6 & 0.74 & 0.89 & 0.29 & 0.18 & $\mathrm{Mg}_{0.74} \mathrm{O}_{0.51}(\mathrm{OH})_{0.47} \mathrm{SiO}_{2} \cdot\left(\mathrm{H}_{2} \mathrm{O}\right)_{0.89}$ & $\mathrm{M}_{0.74} \mathrm{SH}_{1.13}$
\end{tabular}




\begin{tabular}{cccccccl}
0.8 & 0.84 & 1.07 & 0.32 & 0.41 & $\mathrm{Mg}_{0.84} \mathrm{O}_{0.47}(\mathrm{OH})_{0.73} \mathrm{SiO}_{2} \cdot\left(\mathrm{H}_{2} \mathrm{O}\right)_{1.07}$ & $\mathrm{M}_{0.84} \mathrm{SH}_{1.44}$ \\
1.0 & 1.00 & 1.15 & 0.50 & 0.54 & $\mathrm{MgO}_{0.48}(\mathrm{OH})_{1.04} \mathrm{SiO}_{2} \cdot\left(\mathrm{H}_{2} \mathrm{O}\right)_{1.15}$ & $\mathrm{MSH}_{1.67}$ \\
1.3 & 1.25 & 1.45 & 0.69 & 0.57 & $\mathrm{Mg}_{1.25} \mathrm{O}_{0.58}(\mathrm{OH})_{1.26} \mathrm{SiO}_{2} \cdot\left(\mathrm{H}_{2} \mathrm{O}\right)_{1.45}$ & $\mathrm{M}_{1.25} \mathrm{SH}_{2.08}$ \\
1.7 & 1.42 & 1.69 & 0.72 & 0.74 & $\mathrm{Mg}_{1.42} \mathrm{O}_{0.52}(\mathrm{OH})_{1.46} \mathrm{SiO}_{2} \cdot\left(\mathrm{H}_{2} \mathrm{O}\right)_{1.69}$ & $\mathrm{M}_{1.42} \mathrm{SH}_{2.42}$ \\
\hline${ }^{2}$
\end{tabular}

${ }^{a}$ Calculated from the initial $\mathrm{Mg} / \mathrm{Si}$, the amount of brucite (TGA) and unreacted $\mathrm{SiO}_{2}$ as

475 given in Table 2.

$476 \quad{ }^{\mathrm{b}} \mathrm{H}_{2} \mathrm{O} / \mathrm{Si}=$ weight loss $/ \mathrm{Si} \cdot /\left(\mathrm{H}_{2} \mathrm{O}\right) / 100$; from Table

$477{ }^{\mathrm{c}}$ Silanol groups: $\mathrm{Si}-\mathrm{OH} / \mathrm{Si}=2\left(\right.$ weight loss $\left./ \mathrm{Si} \cdot /(\mathrm{OH}) / 100 \cdot\left(2 /\left(\mathrm{Q}^{1}\right)+/\left(\mathrm{Q}^{2}\right)\right) / 100\right)$;

$478{ }^{\mathrm{d}}$ Magnesium hydroxide $\mathrm{Mg}-\mathrm{OH} / \mathrm{Si}=2$ (weight loss $\left./ \mathrm{Si}-\mathrm{H}_{2} \mathrm{O} / \mathrm{Si}-1 / 2 \mathrm{Si}-\mathrm{OH} / \mathrm{Si}\right)$

\subsection{Solution Analyses}

\subsubsection{Dissolved Concentrations and Saturation Indices}

The composition of the solutions in equilibrium with the synthesized M-S-H phases is given in Table 5. At low Mg/Si ratios where amorphous $\mathrm{SiO}_{2}$ persisted even after 1 year, 484 the silica concentrations remained at $1-2 \mathrm{mM}$ and $\mathrm{pH}$ values near 9 were observed. At $485 \mathrm{Mg} / \mathrm{Si}>1$ the measured $\mathrm{Si}$ and $\mathrm{Mg}$ concentrations decreased while the $\mathrm{pH}$ values 486 increased up to 10.5 at $\mathrm{Mg} / \mathrm{Si}=1.7$ (Table 5). A similar strong effect of the $\mathrm{Mg} / \mathrm{Si}$ ratio 487 on the $\mathrm{pH}$ values has been reported previously $[52,53]$.

488 Thermodynamic modelling based on the measured concentrations revealed saturation 489 indices for amorphous $\mathrm{SiO}_{2}$ near 0 for low Mg/Si ratios (see Table 5). This indicates that 490 the solutions were near saturation and consequently supporting the experimental 491 observation of unreacted silica in the precipitated samples. At high $\mathrm{Mg} / \mathrm{Si}$ ratio, the pore 492 solutions were in all cases clearly undersaturated with regard to amorphous $\mathrm{SiO}_{2}$, 
493

494

495

496

497

498

${ }^{\text {a }}$ Amorphous $\mathrm{SiO}_{2}$.

consistent with the absence of amorphous $\mathrm{SiO}_{2}$. At $\mathrm{Mg} / \mathrm{Si} \geq 1.3$, the solutions were near saturation with respect to brucite, which is in accordance with the experimental results.

Table 5: Measured dissolved concentrations in the solutions in equilibrium with the synthesized M-S-H samples and calculated saturation indices at $20^{\circ} \mathrm{C}$.

\begin{tabular}{cccccc|ccc|}
\hline $\mathrm{Mg} / \mathrm{Si}$ & $\mathrm{Mg} / \mathrm{Si}$ & $\mathrm{Si}$ & $\mathrm{Mg}$ & $\mathrm{OH}^{-}$ & \multirow{2}{*}{$\mathrm{pH}^{-}$} & \multicolumn{3}{c}{ saturation indices } \\
total & Solid & $\mathrm{mM}$ & $\mathrm{mM}$ & $\mathrm{mM}$ & & $\mathrm{SiO}_{2}{ }^{\mathrm{a}}$ & brucite & talc \\
\hline 0.4 & 0.64 & 0.81 & 0.14 & 0.003 & 8.6 & -0.3 & -4.1 & 5.6 \\
0.6 & 0.74 & 0.67 & 0.13 & 0.002 & 8.5 & -0.4 & -4.3 & 4.9 \\
0.8 & 0.84 & 1.51 & 0.18 & 0.002 & 8.6 & -0.1 & -4.1 & 6.8 \\
1.0 & 1.00 & 0.25 & 0.17 & 0.005 & 8.9 & -0.9 & -3.4 & 5.5 \\
1.3 & 1.25 & 0.009 & 0.087 & 0.110 & 10.2 & -2.8 & -0.8 & 5.0 \\
1.7 & 1.42 & 0.011 & 0.055 & 0.190 & 10.5 & -2.9 & -0.3 & 5.5 \\
\hline
\end{tabular}

499

500

\subsubsection{Derivation of Solubility Products for M-S-H}

If the composition of the solid phase is known and equilibrium between aqueous and

502 solid phase is attained, solubility products can be obtained from measured aqueous

503 concentrations; e.g. for an M-S-H with a talc like composition $\mathrm{K}_{\mathrm{SO}}\left(\mathrm{M}_{3} \mathrm{~S}_{4} \mathrm{H}_{5}\right)=$ $504\left\{\mathrm{Mg}^{2+}\right\}^{3} \cdot\left\{\mathrm{SiO}_{2}{ }^{0}\right\}^{3} \cdot\left\{\mathrm{OH}^{-}\right\}^{6} \cdot\left\{\mathrm{H}_{2} \mathrm{O}^{+}\right\}^{2} /\left\{\mathrm{M}_{3} \mathrm{~S}_{4} \mathrm{H}_{5}(\right.$ solid) $\}$, where \{\} indicates activity. The solubility 505 product can be shortened to $\mathrm{K}_{\mathrm{SO}}\left(\mathrm{M}_{3} \mathrm{~S}_{4} \mathrm{H}_{5}\right)=\left\{\mathrm{Mg}^{2+}\right\}^{3} \cdot\left\{\mathrm{SiO}_{2}\right\}^{0} \cdot\left\{\mathrm{OH}^{-}\right\}^{6} \cdot\left\{\mathrm{H}_{2} \mathrm{O}^{+}\right\}^{2}$ as the activity 506 of a pure phase equals to 1 by definition. As in the present study equilibrium was 507 approached from oversaturation only, equilibrium might not yet have been reached after 5081 year of experiments and the derived "solubility products" should be considered as 509 tentative only. 
510 In the case of M-S-H, the definition of the solid phase composition is complicated as the 511 experimental findings show that the $\mathrm{Mg} / \mathrm{Si}$ ratio of the synthesised magnesium silicate 512 hydrates varies from approximately 0.7 to 1.5 . The solubility of such low-crystalline 513 solids with variable composition can either be described

514 (i) by defining for each possible composition a separate solubility product, which

(ii) by a solid solution approach, as has been done successfully for calcium silicate hydrates (C-S-H) [55], which also have a highly variable composition. Instead of defining a solubility product for each of the solid phase compositions, only the solubility products of end-members solids (e.g. a high and a low $\mathrm{Mg} / \mathrm{Si}$ ratio $\mathrm{M}-\mathrm{S}-\mathrm{H}$ ) are defined, while the solubility of any intermediate M-S-H composition can be derived from these two end-members. For details on the definition of solid solutions and its applications, see for example refs. [55-57]. As our knowledge about the possible structure of M-S$\mathrm{H}$ is very limited, the most simple solid solution approach was chosen to describe M-S-H solubility: an ideal solid solution between magnesium-silicatehydrates with a high and low Mg/Si ratio as shown in Figure 11a, b. However, more appropriate solid solution models might be developed in the future if we will know more about M-S-H structures. 
532 Although the structure of M-S-H is not known, the observation of mainly $\mathrm{Q}^{3}$ units by ${ }^{29} \mathrm{Si}$

533 NMR, the presence of $\sim 20 \%$ bound water, associated most likely with a magnesium 534 hydroxide layer, and the variation of the $\mathrm{Mg} / \mathrm{Si}$ ratio from 0.7 to 1.5 indicate a structure 535 similar to that of talc $\left(3 \mathrm{MgO} \cdot 4 \mathrm{SiO}_{2} \cdot \mathrm{H}_{2} \mathrm{O}\right)$ with additional $\mathrm{H}_{2} \mathrm{O}$ and $\mathrm{Mg}(\mathrm{OH})_{2}$ in the 536 interlayer or to the presence of talc- and serpentine $\left(3 \mathrm{MgO} \cdot 2 \mathrm{SiO}_{2} \cdot 2 \mathrm{H}_{2} \mathrm{O}\right)$-like precursors. 537 Consequently, these two compositions were used as endmember compositions for the 538 solid solution.

539

540 Table 6: Compilation of solubility products at $20^{\circ} \mathrm{C}$ of the two solid solution endmembers

$541 \quad\left(\mathrm{M}_{3} \mathrm{~S}_{4} \mathrm{H}_{5}\right.$ and $\left.\mathrm{M}_{3} \mathrm{~S}_{2} \mathrm{H}_{5}\right)$ for the samples equilibrated for 1 year.

\begin{tabular}{cccc}
\hline $\mathrm{Mg} / \mathrm{Si}$ & $\mathrm{Mg} / \mathrm{Si}$ & \multicolumn{2}{c}{$\log \mathrm{K}_{\mathrm{s} 0}$ at $20{ }^{\circ} \mathrm{C}$} \\
total & Solid & $\mathrm{M}_{3} \mathrm{~S}_{4} \mathrm{H}_{5}{ }^{a}$ & $\mathrm{M}_{3} \mathrm{~S}_{2} \mathrm{H}_{5}{ }^{\mathrm{b}}$ \\
\hline 0.4 & 0.64 & -57.7 & -51.5 \\
0.6 & 0.74 & -58.4 & -52.1 \\
0.8 & 0.84 & -56.5 & -50.8 \\
1.0 & 1.00 & -57.8 & -50.5 \\
1.3 & 1.25 & -58.3 & -47.1 \\
1.7 & 1.42 & -57.7 & -46.5 \\
\hline \multicolumn{3}{c}{ solubility products $( \pm 0.8)$ refer to: } \\
${ }^{\mathrm{b}} \mathrm{M}_{3} \mathrm{~S}_{4} \mathrm{H}_{5} \Leftrightarrow 3 \mathrm{Mg}^{2+}+4 \mathrm{SiO}_{2}{ }^{0}+6 \mathrm{OH}^{-}+2 \mathrm{H}_{2} \mathrm{O}$ \\
${ }^{\mathrm{c}} \mathrm{M}_{3} \mathrm{~S}_{2} \mathrm{H}_{5} \Leftrightarrow 3 \mathrm{Mg}^{2+}+2 \mathrm{SiO}_{2}{ }^{0}+6 \mathrm{OH}^{-}+2 \mathrm{H}_{2} \mathrm{O}$.
\end{tabular}

545

546 The measured aqueous concentrations given in Table 5 were used to calculate a 547 solubility product for both end-member compositions for each of the experiments as 548 shown in Table 6. If in fact a solid solution can be used to describe M-S-H solubility, the 549 solubility products calculated for the samples which contain M-S-H only, should vary 550 with the $\mathrm{Mg} / \mathrm{Si}$ ratio, while the solubility products in mixtures where both silica fume plus 
569 Comparison of the calculated solubility product for low-Mg/Si M-S-H, $M_{3} S_{4} H_{5}$, with

570

571

572

573

574

575

576

577

578

579 The solubility products of $\mathrm{M}_{3} \mathrm{~S}_{4} \mathrm{H}_{5}$ and $\mathrm{M}_{3} \mathrm{~S}_{2} \mathrm{H}_{5}$ at $20{ }^{\circ} \mathrm{C}$, obtained in Table 7 , were used 580 to calculate the dissolved $\mathrm{Mg}$ and $\mathrm{Si}$ concentrations and the $\mathrm{Mg} / \mathrm{Si}$ ratio in the $\mathrm{M}-\mathrm{S}-\mathrm{H}$ as 581 a function of $\mathrm{pH}$ (Figure 11). After 1 year, the low-Mg/Si $(0.4,0.6$ and 0.8$) \mathrm{M}-\mathrm{S}-\mathrm{H}$ 582 samples showed all a $\mathrm{pH}$ value of $\sim 8.3$ and very similar concentrations, consistent with 583 the presence of two solids, $\mathrm{M}-\mathrm{S}-\mathrm{H}$ and amorphous $\mathrm{SiO}_{2}$. However, in the calculations 584 the measured $\mathrm{Mg}$ concentrations are somewhat underestimated. At higher $\mathrm{Mg} / \mathrm{Si}$, where 585 only M-S-H is present, the calculations indicate a decrease of silica concentrations with 586 increasing $\mathrm{pH}$ which agrees with the measurements as shown in Figure 11. Although 587 brucite has been observed experimentally in the high $\mathrm{Mg} / \mathrm{Si}$ experiments, the measured 588 samples were clearly undersaturated with respect to brucite. The dissolution of brucite 589 seems to be kinetically hindered in these samples and equilibrium is not yet reached 590 after year. 


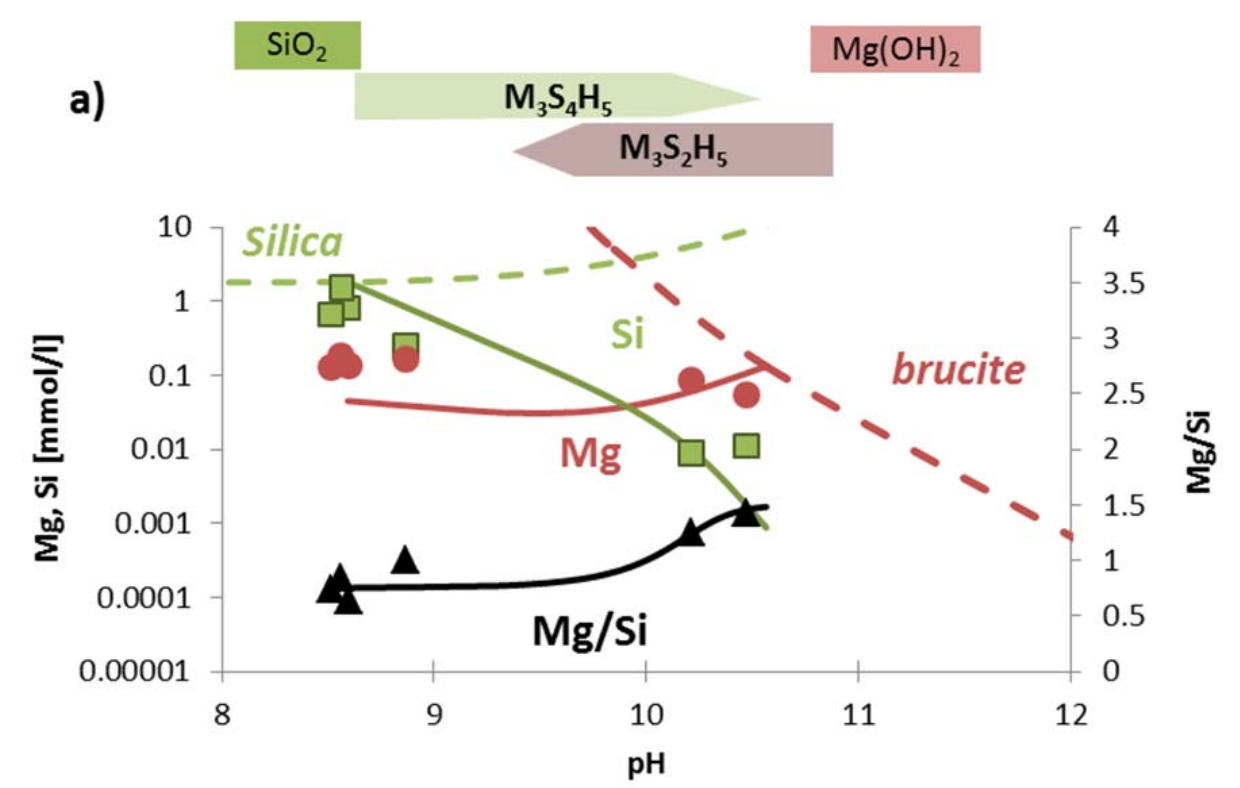

592

b) $\mathrm{SiO}_{2}$

$\mathrm{M}_{3} \mathrm{~S}_{4} \mathrm{H}_{5}$

$\mathrm{Mg}(\mathrm{OH})_{2}$

$\mathrm{M}_{2} \mathrm{~S}_{2} \mathrm{H}_{5}$

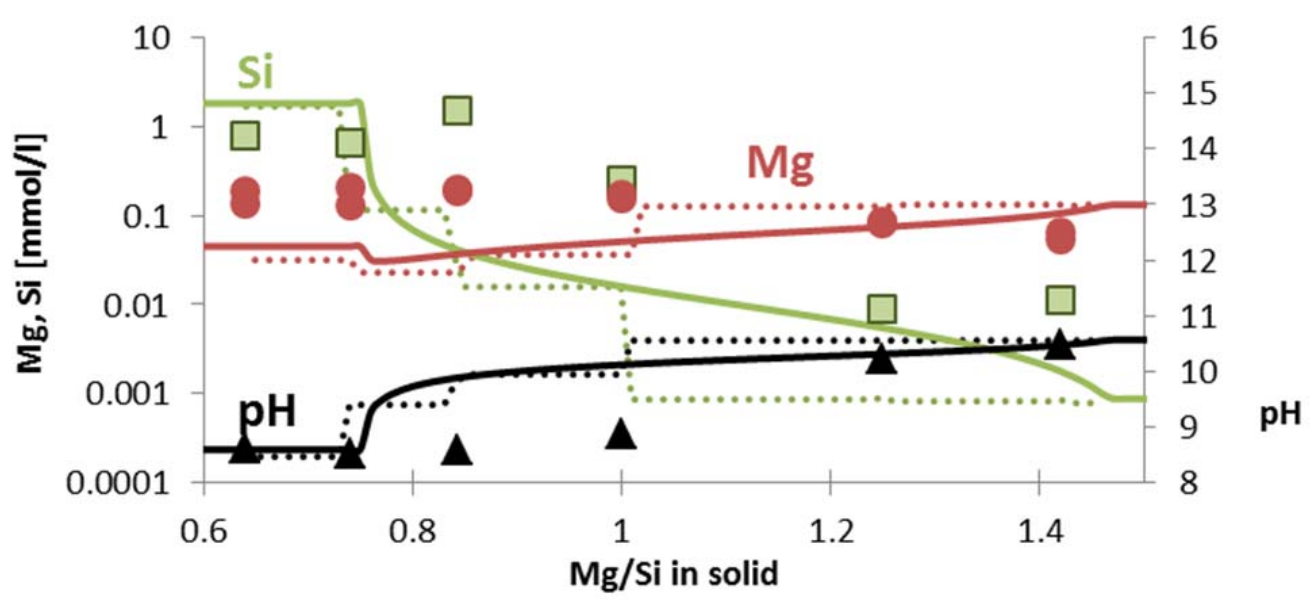

593

594

Figure 11: Mg/Si ratio in M-S-H (triangles), Si (squares) and Mg (circles) concentrations

596 a) as a function of the $\mathrm{pH}$ values and b) as a function of the $\mathrm{Mg} / \mathrm{Si}$ ratio in the solid 597 phase. Dashed lines indicate the solubility of amorphous $\mathrm{SiO}_{2}$ and brucite. For the 598 calculations, i) a solid solution between $\mathrm{M}_{3} \mathrm{~S}_{4} \mathrm{H}_{5}$ and $\mathrm{M}_{3} \mathrm{~S}_{2} \mathrm{H}_{5}$ (see Table 7) was assumed 599 (solid lines) and for comparison ii) single solids (dotted lines) with the composition as 600 determined in Table 4 and using the following solubility products at $20^{\circ} \mathrm{C}\left(\mathrm{M}_{0.64} \mathrm{SH}_{0.78}\right.$ - 
601

602

603

604

605

606

607

608

609

610

611

612

613

614

615

616

617

618

619

620

621

13.0; $\mathrm{M}_{0.74} \mathrm{SH}_{1.13}-14.4 ; \mathrm{M}_{0.84} \mathrm{SH}_{1.14}$-16.0; $\mathrm{MSH}_{1.67}-18.0 ; \mathrm{M}_{1.25} \mathrm{SH}_{2.08}-20.8 ; \mathrm{M}_{1.42} \mathrm{SH}_{2.42}-$ 22.7; referring to $\mathrm{Mg}^{2+}, \mathrm{SiO}_{2}{ }^{0}, \mathrm{OH}^{-}$and $\mathrm{H}_{2} \mathrm{O}$ ) have been used.

\section{Conclusions}

The present contribution shows that $\mathrm{M}-\mathrm{S}-\mathrm{H}$ prepared from $\mathrm{MgO}$ and silica fume is the main hydration product after one year of curing at $20^{\circ} \mathrm{C}$. The $\mathrm{Mg} / \mathrm{Si}$ ratio in synthetic $\mathrm{M}$ S-H varies between 0.7 and 1.5 , for lower ratios unreacted silica remained and for higher ratios brucite precipitated. Thermogravimetric analyses revealed a multistep weight loss for synthetic M-S-H. Up to $280^{\circ} \mathrm{C}$, the sample loses its loosely bound molecular water followed by a stepwise dehydroxylation of $\mathrm{Mg}-\mathrm{OH}$ and $\mathrm{Si}-\mathrm{OH}$. FT-IR as well as ${ }^{29} \mathrm{Si}$ NMR investigations showed a higher polymerization degree of the Si network in $\mathrm{M}-\mathrm{S}-\mathrm{H}$ compared to $\mathrm{C}-\mathrm{S}-\mathrm{H}$, eliminating a single chain-like structure like in C-S-H. A sheet-like structure as in phyllosilicates or a double (triple) chain-like structure like in anthophyllite seems highly possible with stepwise depolymerisation for increasing $\mathrm{Mg} / \mathrm{Si}$ ratios in M-S-H. Raman and XRD investigations support our hypothesis that the $\mathrm{M}-\mathrm{S}-\mathrm{H}$ structure could be related to talc at low $\mathrm{Mg} / \mathrm{Si}$ and to serpentine at higher $\mathrm{Mg} / \mathrm{Si}$. Solubility products for M-S-H calculated on the basis of the aqueous concentrations were used to illustrate the changes observed in the measured concentrations.

Acknowledgments. The authors would like to thank A. Dauzeres, A. Jenni, U. Mäder and B. Schwyn for helpful discussions, E. Bernard for help with the Raman data and the 


\section{References:}

[1] T. Zhang, L.J. Vandeperre, C.R. Cheeseman, Development of magnesium silicate hydrate cement system for nuclear waste encapsulation, in: NUWCEM, Avignon, 2011, pp. 582-591. [2] D. Bonen, M.D. Cohen, Magnesium-sulfate attack on Portland-cement paste. 2. Chemical and mineralogical analyses, Cement and Concrete Research, 22 (1992) 707-718.

[3] M. Santhanam, M.D. Cohen, J. Olek, Sulfate attack research -- whither now?, Cement and Concrete Research, 31 (2001) 845-851.

[4] A. Dauzeres, P. Le Bescop, P. Sardini, C. Cau Dit Coumes, Physico-chemical investigation of clayey/cement-based materials interaction in the context of geological waste disposal:

Experimental approach and results, Cement and Concrete Research, 40 (2010) 1327-1340.

[5] S. Carroll, W. McNab, S. Torres, M. Singleton, P. Zhao, Wellbore integrity in carbon sequestration environments: 1 . Experimental study of Cement-Sandstone/Shale-Brine-CO2, Energy Procedia, 4 (2011) 5186-5194.

[6] A. Jenni, U. Mäder, C. Lerouge, S. Gaboreau, B. Schwyn, In situ interaction between different concretes and Opalinus clay, Physics and Chemistry of the Earth, Parts A/B/C, 70-71 (2014) 7183.

[7] A. Dauzères, G. Achiedo, D. Nied, E. L'Hopital, S. Alahrache, B. Lothenbach, M-S-H precipitation in low-pH concretes in clayey environment, in: NUWCEM 2014, Avignon, France, 2014.

[8] D.R.M. Brew, F.P. Glasser, Synthesis and characterisation of magnesium silicate hydrate gels, Cement and Concrete Research, 35 (2005) 85-98.

[9] J.-B. d'Espinose de Lacaillerie, M. Kermarec, O. Clause, ${ }^{29}$ Si NMR observation of an amorphous magnesium silicate formed during impregnation of silica with $\mathrm{Mg}(\mathrm{II})$ in aqueous solution, Journal of Physical Chemistry, 99 (1995) 17273-17281.

[10] C. Roosz, S. Grangeon, P. Blanc, V. Montouillout, B. Lothenbach, P. Henocq, E. Giffaut, P. Vieillard, S. Gaboreau, Crystal structure of magnesium silicate hydrates (M-S-H): The relation with 2:1 Mg-Si phyllosilicates, Cement and Concrete Research, 73 (2015) 228-237.

[11] K. Chabrol, M. Gressier, N. Pebere, M.-J. Menu, F. Martin, J.-P. Bonino, C. Marichal, J. Brendle, Functionalization of synthetic talc-like phyllosilicates by alkoxyorganosilane grafting, Journal of Materials Chemistry, 20 (2010) 9695-9706.

[12] T. Mitsuda, H. Taguchi, Formation of magnesium silicate hydrate and its crystallzation to talc, Cement and Concrete Research, 7 (1977) 223-230.

[13] G. Whitney, D.D. Eberl, Mineral paragenesis in a talc-water experimental hydrothermal system, American Mineralogist, 67 (1982) 944-949.

[14] J.C.-S. Yang, The system magnesia-silica-water below $300^{\circ} \mathrm{C}$ : I, low-temperature phases from $100^{\circ}$ to $300^{\circ} \mathrm{C}$ and their properties, Journal of the American Ceramic Society, 43 (1960) 542-549.

[15] G.L. Kalousek, D. Mui, Studies on formation and recrystallization of intermediate reaction products in the system magnesia-silica-water, Journal of the American Ceramic Society, 37 (1954) 38-42. 

of silicon nanoparticles, Physica E, 32 (2006) 155-158.

[17] G. Plusquellec, Analyse in situ de suspension de silicate de calcium hydraté: application aux interactions ioniques a la surface des particules in, Université de Bourgogne, Dijon, 2014, pp. 186.

672 Berner, GEM-Selektor geochemical modeling package: revised algorithm and GEMS3K numerical kernel for coupled simulation codes, Computational Geochemistry, 17 (2013) 1-24. [19] W. Hummel, U. Berner, E. Curti, F.J. Pearson, T. Thoenen, Nagra/PSI Chemical Thermodynamic Data Base 01/01, Universal Publishers/UPUBLISH.com, USA, also published as Nagra Technical Report NTB 02-16, Wettingen, Switzerland, 2002.

[20] T. Thoenen, D. Kulik, Nagra/PSI chemical thermodynamic database 01/01 for the GEMSelektor (V.2-PSI) geochemical modeling code, PSI, Villigen; available at http://gems.web.psi.ch/doc/pdf/TM-44-03-04-web.pdf, 2003.

[21] H.C. Helgeson, J.M. Delany, H.W. Nesbitt, D.K. Bird, Summary and critique of the thermodynamic properties of rock forming minerals, American Journal of Science,, 278-A (1978) 229.

[22] T.J.B. Holland, R. Powell, An internally consistent thermodynamic data set for phases of petrological interest, Journal of Metamorphic Geology, 16 (1998) 309-343.

[23] E. Melekhova, M.W. Schmidt, P. Ulmer, E. Guggenbühl, The reaction talc + forsterite = enstatite $+\mathrm{H}_{2} \mathrm{O}$ revisited: Application of convenntional and novel experimental techniques and derivation of revised thermodynamic properties, American Mineralogist, 91 (2006) 1081-1088. [24] B. Perdikatsis, H. Burzlaff, Strukturverfeinerung am Talk $\mathrm{Mg}_{3}\left[(\mathrm{OH})_{2} \mathrm{Si}_{4} \mathrm{O}_{10}\right]$, Zeitschrift für Kristallographie, 156 (1981) 177-186.

[25] H. Konishi, P.R. Buseck, H. Xu, X. Li, Proto-Polymorphs of jimthompsonite and chesterite in contact-metamorphosed serpentinites from Japan, American Mineralogist, 93 (2008) 351-359.

[26] I. Dódony, M. Pósfai, P.R. Buseck, Revised structure models for antigorite: An HRTEM study, American Mineralogist, 87 (2002) 1443-1457.

[27] S.A. Walling, H. Kinoshita, S.A. Bernal, N.C. Collier, J.L. Provis, Structure and properties of binder gels formed in the system $\mathrm{Mg}(\mathrm{OH})_{2}-\mathrm{SiO}_{2}-\mathrm{H}_{2} \mathrm{O}$ for immobilisation of Magnox sludge, Dalton Transactions, (2015) doi: 10.1039/c1035dt00877h.

[28] J. Temuujin, K. Okada, K.J.D. MacKenzie, Formation of layered magnesium silicate during the aging of magnesium hydroxide-silica mixtures, Journal of the American Ceramic Society, 81 (1998) 754-756.

[29] D.G. Park, J.C. Duchamp, T.M. Duncan, J.M. Burlitch, Preparation of forsterite by pyrolysis of a xerogel: The effect of water, Chemistry of Materials, 6 (1994) 1990-1995.

[30] R.L. Frost, J.T. Kloprogge, Infrared emission spectroscopic study of brucite, Spectrochimica Acta Part A: Molecular and Biomolecular Spectroscopy, 55 (1999) 2195-2205.

[31] A. Miller, C.H. Wilkins, Infrared spectra and characteristic frequencies of inorganic ions, , Analyt Chem, 24 (1952) 1253-1294.

[32] Z. Zhang, Y. Zheng, Y. Ni, Z. Liu, J. Chen, X. Liang, Temperature- and pH-dependent morphology and FT-IR analysis of magnesium carbonate hydrates, The Journal of Physical Chemistry B, 110 (2006) 12969-12973.

[33] P. Yu, R.J. Kirkpatrick, B. Poe, P.F. McMillan, X. Cong, Structure of calcium silicate hydrate (C-S-H): Near-, mid-, and far-infrared spectroscopy, Journal of the American Ceramic Society, 82 (1999) 742-748.

[34] G.J. Rosasco, J.J. Blaha, Raman micro-probe spectra and vibrational-mode assingments of talc Applied Spectroscopy, 34 (1980) 140-144 (RRUFFID=R050058).

[35] I. Gunnarsson, S. Arnórsson, S. Jakobsson, Precipitation of poorly crystalline antigorite under hydrothermal conditions, Geochimica et Cosmochimica Acta, 69 (2005) 2813-2828. 
[36] M. Mellini, Y. Fuchs, C. Viti, C. Lemaire, J. Linares, Insights into the antigorite structure from Mössbauer and FTIR spectroscopies, European Journal of Mineralogy, 14 (2002) 97-104. [37] P. Dawson, C.D. Hadfield, G.R. Wilkinson, The polarized infra-red and Raman spectra of $\mathrm{Mg}(\mathrm{OH})_{2}$ and $\mathrm{Ca}(\mathrm{OH})_{2}$, Journal of Physics and Chemistry of Solids, 34 (1973) 1217-1225 (RRUFFID=R040077).

[38] C. Rinaudo, D. Gastaldi, E. Belluso, Characterization of chrysotile, antigorite and lizardite by FT-Raman spectroscopy, Canadian Mineralogist, 41 (2003) 883-890 (Chrysotile:

RRUFFID=R070355; Antigorite: RRUFFID=070228; Lizardite: RUFFID=060006).

[39] B. Lothenbach, F. Winnefeld, Thermodynamic modelling of the hydration of Portland cement, Cem Concr Res, 36 (2006) 209-226.

[40] G.E. Maciel, D.W. Sindorf, V.J. Bartuska, Characterization of silica-attached systems by ${ }^{29} \mathrm{Si}$ and ${ }^{13} \mathrm{C}$ cross-polarization and magic-angle spinning nuclear magnetic resonance, $\mathrm{J}$ Chromatogr, 205 (1981) 438 - 443.

[41] K.J.D. MacKenzie, R.H. Meinhold, Thermal reaction of chrysotile revisited: a ${ }^{29} \mathrm{Si}$ and ${ }^{25} \mathrm{Mg}$ NMR study, American Mineralogist, 79 (1994) 43-50.

[42] E. Lippmaa, M. Mägi, A. Samoson, G. Engelhardt, A.-R. Grimmer, Structural studies of silicates by solid-state high-resolution ${ }^{29} \mathrm{Si}$ NMR, J Am Chem Soc, 102 (1980) $4889-4893$. [43] C.A. Weiss, S.P. Altaner, R.J. Kirkpatrick, High-resolution ${ }^{29}$ Si NMR spectroscopy of 2:1 layer silicates: Correlations among chemical shift, structural distortions and chemical variations, American Mineralogist, 72 (1987) 935-942.

[44] K. Kosuge, K. Shimada, A. Tsunashima, Micropore formation by acid treatment of antigorite, Chemistry of Materials, 7 (1995) 2241-2246.

[45] W. Wieker, A.R. Grimmer, A. Winkler, M. Mägi, M. Tarmak, E. Lippmaa, Solid-state highresolution 29Si NMR spectroscopy of synthetic $14 \AA, 11 \AA$ and $9 \AA$ tobermorites, Cem Concr Res, 12 (1982) 333 - 339.

[46] P.J. Pallister, I.L. Moudrakovski, J.A. Ripmeester, Mg-25 ultra-high field solid state NMR spectroscopy and first principles calculations of magnesium compounds, Physical Chemistry Chemical Physics, 11 (2009) 11487-11500.

[47] F. Zigan, R. Rothbauer, Neutronenbeugungsmessungen am Brucit, Neues Jahrbuch für Mineralogie Monatshefte, 4 (1967) 137 - 143.

[48] J. Skibsted, H.J. Jakobsen, C. Hall, Direct observation of aluminum guest ions in the silicate phases of cement minerals by ${ }^{27}$ Al MAS NMR spectroscopy, J Chem Soc Faraday Trans, 90 (1994) $2095-2098$.

[49] J.-B. d'Espinose de Lacaillerie, C. Fretigny, D. Massiot, MAS NMR spectra of quadrupolar nuclei in disordered model : The Czjzek model, J Magn Reson, 192 (2008) 244-251. [50] J.P. Yesinowski, H. Eckert, G.R. Rossmann, Characterization of hydrous species in minerals by high-speed ${ }^{1}$ H MAS-NMR., J Am Chem Soc, 110 (1998) 1367 - 1375.

[51] R.E.J. Sears, R. Kaliaperumal, S. Manogaran, ${ }^{1} \mathrm{H}$ shielding anisotropy in $\mathrm{Mg}(\mathrm{OH})^{2}$ : the isolated $\mathrm{OH}^{-}$group, J Chem Phys, 88 (1988) 2284-2288.

[52] F. Jin, A. Al-Tabbaa, Strength and hydration products of reactive MgO-silica pastes, Cement and Concrete Composites, 52 (2014) 27-33.

[53] T. Zhang, C.R. Cheeseman, L.J. Vandeperre, Development of low pH cement forming magnesium silicate hydrate (M-S-H), Cement and Concrete Research, 41 (2011) 439-442. [54] A. Trapote-Barreira, J. Cama, J.M. Soler, Dissolution kinetics of C-S-H gel: flow through experiments, Physics and Chemistry of the Earth, 70-71 (2014) 17-31.

[55] D.A. Kulik, Improving the structural consistency of C-S-H solid solution thermodynamic models, Cement and Concrete Research, 41 (2011) 477-495.

[56] D.A. Kulik, M. Kersten, Aqueous Solubility Diagrams for Cementitious Waste Stabilization Systems: II, End-Member Stoichiometries of Ideal Calcium Silicate Hydrate Solid Solutions, Journal of the American Ceramic Society, 84 (2001) 3017-3026. 
766 [57] P.D. Glynn, E.J. Reardon, Solid-solution aqueous-solution equilibria - thermodynamic theory 767 and representation, American Journal of Science, 290 (1990) 164-201.

768

769 